\title{
Functional properties of beetroot (Beta vulgaris) in management of cardio-metabolic diseases
}

\author{
Parvin Mirmiran ${ }^{1}$, Zeinab Houshialsadat ${ }^{1}$, Zahra Gaeini ${ }^{1}$, Zahra Bahadoran ${ }^{1 *}$ and Fereidoun Azizi ${ }^{2}$
}

\begin{abstract}
Red beetroot (Beta vulgaris), as a naturally occurring root vegetable and a rich source of phytochemicals and bioactive compounds, is known for its beneficial roles in the improvement of several clinical and pathologic outcome. Chronic and acute beetroot juice supplementation, as a cost-effective strategy, is proposed to hold promises in controlling diabetes and insulin hemostasis, blood pressure and vascular function, renal health and the possible effect on microbiome abundance. The secondary outcome and physiological response of microbiome abundance modulation included the non- significant fluctuation of systolic and diastolic blood pressures. Also, some studies have suggested a reno-protective property of beetroot juice that is associated with the reduction of mortality rate and favorable changes in kidney's functional parameters among patients with renal disorders. Similarly, it is shown that the persistent consumption of beetroot juice effectively postpones the postprandial glycemic response and decreases the blood glucose peak. The significant blood pressure lowering effect has been seen among normotensive subjects, which tend to be more considerable among hypertensive individuals and progressive among overweight adults.

Within this context, this review aims to provide a comprehensive overview on the therapeutic applications of beetroot juice in metabolic disorders and theirs underlying mechanisms. Despite the inconsistencies in the set of results from the reviewed studies, there is no doubt that further contributing factors must be investigated more deeply in future studies.
\end{abstract}

Keywords: Beetroot, Hypertension, Diabetes, Kidney function, Nitric oxide

\section{Introduction}

Beetroot, an annual or biennial cultivated form of Beta vulgaris subsp. vulgaris conditiva, includes a variety of edible taproots originated from the Middle East, which has been spreading worldwide, from the Americas to Europe and Asia [1,2]. As a rich and nutritious source, it is believed to hold health-promotional characteristics, anti-oxidant and anti-inflammatory effects [3], anticarcinogenic and anti-diabetic activities and hepatoprotective, hypotensive and wound healing properties $[4$, 5]. Therefore, beetroot is currently being applied as a functional ingredient in the development of various

\footnotetext{
* Correspondence: zahrabahadoran@yahoo.com

${ }^{1}$ Nutrition and Endocrine Research Center, Research Institute for Endocrine Sciences, Shahid Beheshti University of Medical Sciences, Tehran, No. 24, Sahid-Erabi St, Yemen St, Chamran Exp, Tehran, Iran

Full list of author information is available at the end of the article
}

meals $[6,7]$. It is notable that most recent studies on beetroot supplementation, especially those addressing its hypotensive and ergogenic properties, emphasized the critical role of inorganic $\mathrm{NO}_{3}$ on the clinical effect of this vegetable and its byproducts.

So far, various interventional studies from selective literature have explored and addressed the implications of beetroot and its byproducts on systolic and diastolic blood pressures, vascular and endothelial function, insulin and glucose responses within the glycemic homeostatic context, and the abundance of microbiome. The overall results were ultimately found to be mostly inconsistent. Also, the hypotensive and hypoglycemic effect of beetroot juice consumption had not been firmly attributed to one and major responsible mechanism; such analytic vision was seen across microbial and renal studies as well. 
This comprehensive review provided a detailed, reliable proof on the treatment of the elevated renal parameters including renal resistive index and arterial stiffness with beetroot and its components. Additionally, within this review we aim to provide an updated summery of beetroot consumption and its ultimate effects on blood glucose, blood pressure and microbiome levels, vascular and renal function and therefore, incidence of metabolic syndrome. Findings from this review are useful in addressing mechanisms involved in key metabolic areas and a wrap up on different aspects of each study.

The achievement of this goal paves the way of taking further pharmacological and nutritional advantages in the prevention and treatment levels and bring new perspectives into such multidisciplinary field. With the constant evolving matter of science, this review is one of its kind in the past few years that reported the metabolic effect of beetroot juice on different populations.

\section{Nutrients and bioactive compounds of beetroot}

Beetroot is consist of multiple biologically active phytochemicals including betalains [8] (e.g., betacyanins and betaxanthins), flavonoids, polyphenols, Saponins [8] and inorganic Nitrate $\left(\mathrm{NO}_{3}\right)$; it is also a rich source of diverse minerals such as potassium, sodium, phosphorous, calcium, magnesium, copper, iron, zinc and manganese [9]. It is commonly consumed in form of supplemental juice, powder, bread, gel, boiled, oven-dried, pickled, pureed or jam-processed across different food cultures [1, 10, 11]. As shown in Table $1,100 \mathrm{~mL}$ of beetroot juice is comprised of $95 \mathrm{Kcal}$ energy, $22.6 \mathrm{~g}$ carbohydrates, 0.70 $\mathrm{g}$ proteins, $0.16 \mathrm{~g}$ total lipids, $0.91 \mathrm{~g}$ total dietary fiber and $12 \mathrm{~g}$ total sugars. As such, the micro nutritional composition of $100 \mathrm{~mL}$ beetroot juice is estimated as 8.8 $\mathrm{g}$ sucrose, $0.86 \mathrm{~g}$ fructose, and $2.5 \mathrm{~g}$ glucose [8].

Moreover, various commercial organic and conventional beetroot juices, are reported to contain total sugar, vitamin $\mathrm{C}$ and total flavonoids within a range of 1.73$7.85 \mathrm{~g}, 10.75-20.36 \mathrm{mg}$, and $2.02-2.36 \mathrm{mg}$ (per $100 \mathrm{~g}$ ), respectively [12]. Betalains make up to $\sim 70-100 \%$ of phenolic composition of beetroot, limited to $0.8-1.3 \mathrm{~g} / \mathrm{L}$ of fresh beetroot juice (about 60\% betacyanins and $40 \%$ betaxanthins) [1].

In fact, beetroot is classified as one of the ten plants with the highest antioxidant activity [8]. It is believed to be the main commercial source of betalains, as in concentrated forms, powder, or natural dyes in gelatins, confectionery, dairy, meat, and poultry derived products [8]. According to Baião et al. flavonoids undergo changes following vegetable processing while polyphenols remain active after in vitro digestion, yet found in the highest ratio in beetroot gel than other conformations including beetroot juice [8].
Table 1 Nutrient composition of beetroot and its byproducts (per $100 \mathrm{~g}$ or $\mathrm{L}$ )

\begin{tabular}{|c|c|c|c|c|}
\hline & Raw & Cooked, boiled & Canned & Fresh juice \\
\hline Water, g & 87.58 & 87.06 & 90.96 & - \\
\hline Energy, kcal & 43 & 44 & 31 & 30 \\
\hline Protein, $g$ & 1.61 & 1.68 & 0.91 & 1.02 \\
\hline Total fats, g & 0.17 & 0.18 & 0.14 & 0 \\
\hline Carbohydrate, g & 9.56 & 9.96 & 7.21 & 6.6 \\
\hline Fiber, $g$ & 2.8 & 2 & 1.8 & 0 \\
\hline Sugars, g & 6.76 & 7.96 & 5.51 & 6.6 \\
\hline Calcium, mg & 16 & 16 & 15 & 0 \\
\hline Iron, mg & 0.8 & 0.79 & 1.82 & 0 \\
\hline Magnesium, mg & 23 & 23 & 17 & - \\
\hline Phosphorus, mg & 40 & 38 & 17 & - \\
\hline Potassium, mg & 325 & 305 & 148 & - \\
\hline Sodium, mg & 78 & 77 & 194 & 93 \\
\hline Zinc, mg & 0.35 & 0.35 & 0.21 & - \\
\hline Vitamin C, mg & 4.9 & 3.6 & 4.1 & 0 \\
\hline Thiamin, mg & 0.031 & 0.027 & 0.01 & - \\
\hline Riboflavin, mg & 0.04 & 0.04 & 0.04 & - \\
\hline Niacin, mg & 0.334 & 0.331 & 0.157 & - \\
\hline Folate, $\mu \mathrm{g}$ & 109 & 80 & 30 & - \\
\hline Total phenolic content ${ }^{\mathrm{a}}$ & 255 & 238 & 192 & 225 \\
\hline Total flavonoid content ${ }^{\mathrm{b}}$ & 260 & 261 & 173 & 126 \\
\hline
\end{tabular}

${ }^{a}$ As mg gallic acid equivalent (GAE)/ $100 \mathrm{~g} ;{ }^{\mathrm{b}}$ as mg rutin equivalent (RE)/100 g sample

$\mathrm{NO}_{3}$ contributes as one of the most important inorganic compounds within beetroot, the content of which is reported to vary 10 -fold between single varieties [1]. $\mathrm{NO}_{3}$ concentration was said to be within a range of $388 \pm 19.9$ to $3968 \pm 252 \mathrm{mg} / \mathrm{L}$ among commercial beetroot juice and $393 \pm 2.23$ to $2721 \pm 54.4 \mathrm{mg} / \mathrm{L}$ among commercial beetroot powders. Although nitrate is relatively inert, it is yet capable of transforming status into $\mathrm{NO}_{2}$ through bacterial enzymatic pathways $\left(\mathrm{NO}_{3}\right.$ reductase), which subsequently is non- enzymatically decomposed to NO in the oral cavity. The classification of the beetroot organ in terms of $\mathrm{NO}_{3}$ concentration from highest to lowest is as petiole, leaf, stem, root, tuber, bulb, fruit, and seed, respectively [8].

Additionally, the oxalic acid constitution of beetroot is relatively abundant [13]; average content in raw beetroot and beetroot juice equals to $94.6-141.6 \mathrm{mg} / 100 \mathrm{~g}$ and $300-525 \mathrm{mg} / \mathrm{L}$, respectively. Oxalic acid, as a metal ion chelator, promotes the formation of nephroliths, and therefore, is considered as a health concern especially in patients predisposed to the kidney disease $[1,14]$.

With the challenge of formulating biologically safe, $\mathrm{NO}_{3-}$ rich beetroot supplements, various preparation methods such as beetroot juice freeze-drying for the 
production of beetroot powder, have initially been introduced. Red round thin beetroot chips and pseudoplastic beetroot gels are also of the most recently invented and functional forms of beetroot supplements. Beetroot chips are known to contain the highest energy content (Kcal), carbohydrate and total sugar, the highest value of Total Antioxidant Potential (TAP) and the lowest value of Total Phenolic Content (TPC), flavonoids and Saponin level. The pseudoplastic gel, as a mean of $\mathrm{NO}_{3}$ administration to athletes, is believed to contain the highest protein and lowest lipid content, ranking beetroot gel not as the most commonly used but most effective formulation comparing to other byproducts [8].

Despite the industrial food exploitation of red beet, sugar beet is grown commercially for sugar production due to the high content of sucrose [1]. The processing of the sugar depends on the nitrogen availability, especially in the early stages of growth $[15,16]$.

\section{Effects of beetroot on blood pressure and vascular function}

The awareness regarding the impact of acute and chronic beetroot juice consumption on blood pressure and vascular function by clinical studies is rapidly rising (Tables 2 and 3). Within this review, we investigated a total of 25 human studies. The number of studies with emphasis on the blood pressure lowering properties among normotensive and hypertensive individuals in different health states, overwhelms those contradicting this outcome. The role of nitrate- nitrite pathway and that of bioactive compounds are highlighted.

For the first time, Webb et al. performed an openlabel cross-over study in healthy volunteers to support the blood pressure lowering properties of a $\mathrm{NO}_{3}$ concentrated beetroot juice [14]. This result was confirmed by a meta-analysis of 12 randomized clinical trials by Siervo et al., which highlighted the cardio-protective properties of beetroot juice supplementation in accordance to a significant effect size on systolic blood pressure (SBP) (mean difference $=-4.5,95 \% \mathrm{CI}=-6.4,-2.5)$ [44]. This study investigated the acute hypotensive properties of beetroot juice, and highlighted the significant association between a daily dose of inorganic $\mathrm{NO}_{3}$ (as a biomarker of $\mathrm{NO}$ availability, provided as sodium $\mathrm{NO}_{3}$ or beetroot juice) and changes in SBP [44].

Additionally, the ingestion of white-beetroot bread $(\sim 4.5 \mathrm{mg}$ betacyanin $/ 100 \mathrm{~g})$ and red-beetroot bread $(\sim 27.3 \mathrm{mg}$ betacyanin $/ 100 \mathrm{~g}$ ), with equivalent doses of $\mathrm{NO}_{3}$, is believed to decrease blood pressure to the same extent, affirming a positive linkage among $\mathrm{NO}_{3}$ content and the observed blood pressure lowering effect of beetroot [45]. Beetroot juice consumption was also shown to reduce blood pressure, improve endothelial function, and dramatically increase the plasma $\mathrm{NO}_{2}$ level and systemic
NO production [38]. In healthy subjects, consumption of $500 \mathrm{~mL}$ beetroot juice substantially decreased blood pressure in proportion to an increased peak of plasma $\mathrm{NO}_{2}$ level [46].

In contrary to the most common conclusion, emphasizing the exclusive role of $\mathrm{NO}_{3}$ on the hypotensive effect of beetroot, a recent meta-analysis highlighted the potential $\mathrm{NO}_{3}$ independent blood pressure lowering effect and postulated a dose-dependent relationship between inorganic $\mathrm{NO}_{3}$ and its hypotensive effect [47]. There are other studies in agreement with this investigation, which have indicated a similar microvascular, vasodilator property following the consumption of NO3rich beetroot juice, compared to a NO3- depleted placebo, within a period of 24days [28]; hence, it is suggested that bioactive components other than NO3, may mediate dilatory responses among both beverages [6].

Hypotensive effect of beetroot seems to be highly influenced by physiological and medical status. Beetroot juice administration was found to exert a much stronger effect on blood pressure in hypertensive compared to normotensive subjects, which can be explained by the rate of erythrocyte xanthine oxidase expression (XOR Erythrocytic Xanthine Oxidoreductase, an enzyme involved in reduction of $\mathrm{NO}_{2}$ in active $\mathrm{NO}$ ) in hypertensive states [40].

As a counterpoint, despite elevations in plasma $\mathrm{NO}_{2}$ concentration, no significant decrease of blood pressure has been admitted in diabetic patients supplemented with $250 \mathrm{~mL}$ beetroot juice for 2 weeks. The reason for this discrepant result is unclear but may reflect the study methodology, related to concomitant medications or aberrant vascular physiology in diabetic patients [28].

Similarly, the study of Ghosh et al. on 40 hypertensive pregnant women extended our findings on the efficacy of dietary nitrate supplementation in form of $70 \mathrm{~mL}$ beetroot juice comparing to control. It was concluded that the ingestion of a single dose of dietary nitrate, does not provide a considerable difference between the two groups at any time points. Although the acute ingestion led to an elevation of diastolic blood pressure (DBP), this measurement returned to the baseline value by the first $24 \mathrm{~h}$ and the subsequent first week and therefore, no significant differences in plasma nitrate or nitrite level could be observed. It was however confirmed that a considerable correlation exists among alterations of plasma nitrite conversion and concentration rates, and blood pressure responses, which was consistent with the previous biochemical data and other modalities. With that said, interventions involving dietary nitrate may only appear effective if the individual is capable of undergoing nitrate to nitrite bioconversion or assimilating abilities [40]. 
Table 2 Chronic effects of beetroot on blood pressure and vascular function

\begin{tabular}{|c|c|c|c|c|c|c|}
\hline Author & Study population & Study Design & $\begin{array}{l}\text { Sample } \\
\text { Size }\end{array}$ & $\begin{array}{l}\text { Duration } \\
\text { (days) }\end{array}$ & $\begin{array}{l}\text { Dose of beetroot and its } \\
\text { corresponding } \mathrm{NO}_{3} \text { content }\end{array}$ & Findings \\
\hline $\begin{array}{l}\text { Shepherd } \\
\text { et al. [17] }\end{array}$ & COPD Patients & $\begin{array}{l}\text { Randomized, } \\
\text { double blind, } \\
\text { placebo } \\
\text { controlled }\end{array}$ & 13 & 2.5 & $\begin{array}{l}\text { Consumption of } 70 \mathrm{ml} \text { of } \\
\left.\text { beetroot juice }(\sim 430 \mathrm{mg} \mathrm{NO})_{3}\right) \\
\text { vs. } \mathrm{NO}_{3} \text {-depleted beetroot juice } \\
\text { twice a day }\end{array}$ & No effect on DBP or SBP \\
\hline $\begin{array}{l}\text { Keen et al. } \\
{[18]}\end{array}$ & Healthy non-smokers & $\begin{array}{l}\text { Randomized, } \\
\text { double blind, } \\
\text { placebo } \\
\text { controlled }\end{array}$ & 6 & 3 & $\begin{array}{l}\text { Daily consumption of } 70 \mathrm{ml} \text { of } \\
\text { beetroot juice }(\sim 450 \mathrm{mg} \mathrm{NO})\end{array}$ & $\downarrow$ Mean arterial BP, $\downarrow$ DBP \\
\hline $\begin{array}{l}\text { Kelly et al. } \\
{[19]}\end{array}$ & Healthy adults & $\begin{array}{l}\text { Randomized, } \\
\text { double blind, } \\
\text { cross-over }\end{array}$ & 20 & 3 & $\begin{array}{l}\text { Daily consumption of } 140 \mathrm{ml} \text { of } \\
\text { beetroot juice }\left(\sim 595 \mathrm{mg} \mathrm{NO}_{3}\right) \\
\text { vs. } \mathrm{NO}_{3} \text {-depleted beetroot juice }\end{array}$ & $\downarrow$ Mean arterial BP, $\downarrow$ SBP and DBP \\
\hline $\begin{array}{l}\text { Bailey et al. } \\
\text { [20] }\end{array}$ & Healthy adults & $\begin{array}{l}\text { Randomized, } \\
\text { double blind, } \\
\text { cross-over }\end{array}$ & 9 & 6 & $\begin{array}{l}\text { Daily consumption of } 140 \mathrm{~mL} \\
\text { beetroot juice }\left(\sim 520 \mathrm{mg} \mathrm{NO}_{3}\right) \\
\text { vs. no intervention }\end{array}$ & $\downarrow$ Mean arterial BP, $\downarrow$ SBP and DBP \\
\hline $\begin{array}{l}\text { Bailey et al. } \\
\text { [21] }\end{array}$ & Normotensive men & $\begin{array}{l}\text { Double-blind, } \\
\text { cross-over } \\
\text { placebo- } \\
\text { controlled }\end{array}$ & 8 & 6 & $\begin{array}{l}\text { Daily consumption of } 500 \mathrm{~mL} \\
\text { beetroot juice }\left(\sim 690 \mathrm{mg} \mathrm{NO}_{3}\right) \\
\text { vs. blackcurrant Juice }\end{array}$ & $\downarrow \mathrm{SBP}$ \\
\hline $\begin{array}{l}\text { Bailey et al. } \\
\text { [21] }\end{array}$ & Healthy active men & $\begin{array}{l}\text { Randomized, } \\
\text { double blind, } \\
\text { cross-over }\end{array}$ & 9 & 6 & $\begin{array}{l}\text { Daily consumption of } 500 \mathrm{~mL} \\
\text { beetroot juice }\left(\sim 320 \mathrm{mg} \mathrm{NO} \mathrm{N}_{3}\right) \\
\text { vs. blackcurrant Juice }\end{array}$ & $\downarrow$ Mean arterial BP, $\downarrow$ SBP and DBP \\
\hline $\begin{array}{l}\text { Cermak } \\
\text { et al. [22] }\end{array}$ & Normotensive men & $\begin{array}{l}\text { Double-blind, } \\
\text { repeated- } \\
\text { measures cross- } \\
\text { over }\end{array}$ & 20 & 6 & $\begin{array}{l}\text { Daily consumption of } 140 \mathrm{ml} \text { of } \\
\text { beetroot juice }\left(\sim 490 \mathrm{mg} \mathrm{NO}_{3}\right) \\
\text { vs. } \mathrm{NO}_{3} \text {-depleted beetroot juice }\end{array}$ & No effect on DBP or SBP \\
\hline $\begin{array}{l}\text { Lansley et al. } \\
{[23]}\end{array}$ & Healthy active men & $\begin{array}{l}\text { Randomized, } \\
\text { double blind, } \\
\text { cross-over }\end{array}$ & 9 & 6 & $\begin{array}{l}\text { Daily consumption of } 500 \mathrm{ml} \text { of } \\
\left.\text { beetroot juice }(\sim 3 \mathrm{mg} \mathrm{NO})_{3}\right) \text { vs. } \\
\mathrm{NO}_{3} \text {-depleted beetroot juice }\end{array}$ & $\downarrow$ SBP, no effect on DBP or arterial BP \\
\hline $\begin{array}{l}\text { Bailey et al. } \\
\text { [24] }\end{array}$ & $\begin{array}{l}\text { Healthy smokers and } \\
\text { healthy non-smokers }\end{array}$ & $\begin{array}{l}\text { Double-blind, } \\
\text { cross-over }\end{array}$ & 17 & 6 & $\begin{array}{l}\text { Daily consumption of } 140 \mathrm{~mL} \\
\text { beetroot juice }(\sim 520 \mathrm{mg} \mathrm{NO} \\
\text { vs. } \mathrm{NO}_{3} \text {-depleted beetroot juice } \\
(\sim 5 \mathrm{mg} \mathrm{NO})\end{array}$ & $\downarrow$ SBP in non-smokers \\
\hline $\begin{array}{l}\text { Lara et al. } \\
{[25]}\end{array}$ & $\begin{array}{l}\text { Overweight and } \\
\text { obese adults }\end{array}$ & $\begin{array}{l}\text { randomized, } \\
\text { non-blinded Par- } \\
\text { allel design, }\end{array}$ & 30 & 7 & $\begin{array}{l}\text { Daily consumption of } 70 \mathrm{~mL} \\
\text { beetroot juice }\left(\sim 600 \mathrm{mg} \mathrm{NO}_{3}\right) \\
\text { vs. no intervention }\end{array}$ & $\begin{array}{l}\text { No effect on resting or ambulatory } \\
\text { BP, pulse wave velocity or arterial } \\
\text { distensibility, no change in } \\
\text { asymmetric dimethylarginine (ADMA) }\end{array}$ \\
\hline $\begin{array}{l}\text { Bondonno } \\
\text { et al. [26] }\end{array}$ & Hypertensive adults & $\begin{array}{l}\text { randomized, } \\
\text { double-blind } \\
\text { placebo- } \\
\text { controlled, cross- } \\
\text { over }\end{array}$ & 27 & 7 & $\begin{array}{l}\text { Daily consumption of } 140 \mathrm{~mL} \\
\left.\text { beetroot juice }(\sim 420 \mathrm{mg} \mathrm{NO})_{3}\right) \\
\text { vs. } \mathrm{NO}_{3} \text {-depleted beetroot juice }\end{array}$ & No effect on BP \\
\hline $\begin{array}{l}\text { Kerley et al. } \\
{[27]}\end{array}$ & $\begin{array}{l}\text { Controlled and } \\
\text { uncontrolled } \\
\text { hypertensive patients }\end{array}$ & $\begin{array}{l}\text { Uncontrolled, } \\
\text { pilot }\end{array}$ & 19 & 14 & $\begin{array}{l}140 \mathrm{ml} \text { beetroot juice }(\sim 800 \\
\left.\mathrm{mg} \mathrm{NO}_{3}\right)\end{array}$ & $\begin{array}{l}\downarrow D B P \text { and } \downarrow \text { arterial stiffness in } \\
\text { uncontrolled patients }\end{array}$ \\
\hline $\begin{array}{l}\text { Gilchrist } \\
\text { et al. [28] }\end{array}$ & $\begin{array}{l}\text { Type } 2 \text { diabetic } \\
\text { patients }\end{array}$ & $\begin{array}{l}\text { Randomized } \\
\text { double blind, } \\
\text { placebo- } \\
\text { controlled } \\
\text { crossover }\end{array}$ & 27 & 14 & $\begin{array}{l}\text { Daily consumption of } 250 \mathrm{~mL} \\
\left.\text { beetroot juice }(\sim 500 \mathrm{mg} \mathrm{NO})_{3}\right) \\
\text { vs. } \mathrm{NO}_{3} \text {-depleted beetroot juice }\end{array}$ & $\begin{array}{l}\text { No effect on BP or macro- or } \\
\text { microvascular endothelial function }\end{array}$ \\
\hline $\begin{array}{l}\text { Asgary et al. } \\
\text { [29] }\end{array}$ & $\begin{array}{l}\text { Hypertensive un- } \\
\text { treated adults }\end{array}$ & $\begin{array}{l}\text { Randomized, } \\
\text { single-blind, } \\
\text { crossover }\end{array}$ & 24 & 14 & $\begin{array}{l}\text { Daily consumption of } 250 \mathrm{~mL} \\
\text { beetroot juice vs. } 250 \mathrm{~g} \text { cooked } \\
\text { beetroot }\end{array}$ & $\begin{array}{l}\downarrow \text { SBP and DBP, } \uparrow \text { flow mediated } \\
\text { dilation } \\
\downarrow \text { Intracellular adhesion molecule- } 1 \\
\text { and vascular cell adhesion molecule- } \\
1, \downarrow \text { E-selectin }\end{array}$ \\
\hline $\begin{array}{l}\text { Vanhatalo } \\
\text { et al. [30] }\end{array}$ & Healthy subjects & $\begin{array}{l}\text { Randomized, } \\
\text { assessor-blind, } \\
\text { crossover }\end{array}$ & 8 & 15 & $\begin{array}{l}\text { Daily consumption of } 500 \mathrm{~mL} \\
\text { beetroot juice }(\sim 322 \mathrm{mg} \mathrm{NO}) \\
\text { vs. } 500 \mathrm{~mL} \text { low-calorie juice }\end{array}$ & $\begin{array}{l}\downarrow \text { SBP and mean arterial blood } \\
\text { pressure }\end{array}$ \\
\hline
\end{tabular}


Table 2 Chronic effects of beetroot on blood pressure and vascular function (Continued)

\begin{tabular}{|c|c|c|c|c|c|c|}
\hline Author & Study population & Study Design & $\begin{array}{l}\text { Sample } \\
\text { Size }\end{array}$ & $\begin{array}{l}\text { Duration } \\
\text { (days) }\end{array}$ & $\begin{array}{l}\text { Dose of beetroot and its } \\
\text { corresponding } \mathrm{NO}_{3} \text { content }\end{array}$ & Findings \\
\hline $\begin{array}{l}\text { Jajja et al. } \\
\text { [31] }\end{array}$ & $\begin{array}{l}\text { Overweight older } \\
\text { adults }\end{array}$ & $\begin{array}{l}\text { Parallel, } \\
\text { randomized } \\
\text { clinical }\end{array}$ & 24 & 21 & $\begin{array}{l}\text { Daily consumption of } 70 \mathrm{~mL} \text { of } \\
\text { concentrated beetroot juice }(\sim \\
300-400 \mathrm{mg} \mathrm{NO}) \text { vs. } \\
\text { blackcurrant juice }(\sim 2.7 \mathrm{mg} \\
\left.\mathrm{NO}_{3}\right)\end{array}$ & $\begin{array}{l}\text { No effect on resting clinic BP or } 24-h \\
\text { ambulatory, } \downarrow \text { home-monitoring daily } \\
\text { SBP }\end{array}$ \\
\hline $\begin{array}{l}\text { Kapil et al. } \\
{[32]}\end{array}$ & $\begin{array}{l}\text { Hypertensive older } \\
\text { adults }\end{array}$ & $\begin{array}{l}\text { Randomized, } \\
\text { phase2, double- } \\
\text { blind, placebo- } \\
\text { controlled study }\end{array}$ & 68 & 28 & $\begin{array}{l}\text { Daily consumption of } 250 \mathrm{~mL} \\
\text { beetroot juice }(\sim 450 \mathrm{mg} \mathrm{NO} \text { ) } \\
\text { vs. } \mathrm{NO}_{3} \text {-depleted beetroot juice }\end{array}$ & $\begin{array}{l}\downarrow B P \text {, improve endothelial function, } \downarrow \\
\text { arterial stiffness }\end{array}$ \\
\hline $\begin{array}{l}\text { Velmurugan } \\
\text { et al. [33] }\end{array}$ & $\begin{array}{l}\text { Subjects with } \\
\text { hypercholesterolemia }\end{array}$ & $\begin{array}{l}\text { Randomized, } \\
\text { double-blind, } \\
\text { placebo- } \\
\text { controlled } \\
\text { parallel }\end{array}$ & 69 & 42 & $\begin{array}{l}\text { Daily consumption of } 250 \mathrm{~mL} \\
\text { beetroot juice }(\sim 370 \mathrm{mg} \mathrm{NO} \\
\text { vs. } \mathrm{NO}_{3} \text {-depleted beetroot juice }\end{array}$ & $\begin{array}{l}\downarrow \text { SBP } \\
\uparrow \text { Flow mediated dilation, } \downarrow \text { pulse } \\
\text { wave velocity, } \downarrow \text { augmentation index } \\
\downarrow \text { Platelet-monocyte aggregates } \\
\downarrow \text { P-selectin expression }\end{array}$ \\
\hline
\end{tabular}

NO Nitric Oxide, COPD Chronic Obstructive Pulmonary Disease, DBP Diastolic Blood Pressure, SBP Systolic Blood Pressure

The unsustain blood pressure lowering properties, is another substantial topic. A randomized parallel, clinical trial by Jajja et al. among overweight older adults, revealed a progressive decline in SBP measurements following a 3 week beetroot juice supplementation, which returned to the baseline 1 week post-intervention; accordingly, it was concluded that continuous beetroot supplementation might be necessary to sustain beneficial cardiovascular effects [31].

The ultrasound flow-mediated dilatation measurement (FMD) and aortic pulse wave velocity (aPWV) were the primary methods of investigating the potential short and long term effects of beetroot consumption on vascular function. A 6 week supplementation with $\mathrm{NO}_{3}$ - rich beetroot juice led to a modest improvement of FMD, the aPWV and the augmentation index, and measures of arterial stiffness [45]. Another newly published metaanalysis of clinical studies, reported a significant pooled effect size on FMD following consumption of beetroot juice (standardized mean difference $=0.30,95 \% \mathrm{CI}=$ 0.05-0.54), the result of which was similar to impact of pure inorganic $\mathrm{NO}_{3}$ (administrated as sodium or potassium NO3) (standardized mean difference $=0.54,95 \%$ $\mathrm{CI}=0.21-0.86$ ) [48]. Notably, vascular responsive features to beetroot supplementation can be affected by vascular aging due to a substantial decrease in the $\mathrm{NO}_{3}$ to $\mathrm{NO}_{2}$ bioconversion capacity; Siervo et al., in a recent meta-analysis, assessed the effect of high $\mathrm{NO}_{3}$ beetroot juice on blood pressure variability (24-h ambulatory BP monitoring) and reported a more significant decrease in nocturnal SBP variability in subjects aged $<65$ years compared to the older group ( $\geq 65 \mathrm{y}$ ) [49].

In contrary, a 7 day treatment with high- $\mathrm{NO}_{3}$ concentrated beetroot juice seemed to have no significant effect on resting or ambulatory blood pressure, aPWV and arterial distensibility among overweight and obese older adults; the plasma concentration of asymmetric dimethylarginine (ADMA), an endogenous inhibitor of NO synthesis and a novel risk marker of cardiovascular disease, were additionally remained unaffected by beetroot supplementation [25].

Whether the $\mathrm{NO}_{3}$ is responsible for the leading, beneficial effects of beetroot, can be looked at as a controversial topic. The physiological effects of beetroot is suggested to have a direct relationship with its $\mathrm{NO}_{3}$ content beyond other bioactive compounds including betacyanins (Fig. 1); mechanisms underlying the hypotensive properties of beetroot is also most likely attributed to an enhancement of NO bioavailability as a result of increased non-enzymatic reduction of $\mathrm{NO}_{3}$ into $\mathrm{NO}_{2}$ and $\mathrm{NO}[36,50]$. The pharmacokinetics of $\mathrm{NO}_{3}$ are suggested to differ based on the delivery vehicle [51, 52], in which beetroot was used as in the vast majority of clinical studies, investigating the hypotensive effect of $\mathrm{NO}_{3}$ $[26,31,35,50-52]$. The non- significant blood pressure lowering effect of $\mathrm{NO}_{3}$ - depleted beetroot compared to $\mathrm{NO}_{3}$ - rich beetroot $[32,41]$, may imply the key and potential role of $\mathrm{NO}_{3}$ versus other beetroot's nutraceuticals. It is reported that the hypotensive properties of beetroot are proportional to the high turnover of $\mathrm{NO}_{3} /$ $\mathrm{NO}_{2}$ and cyclic guanosine monophosphate (cGMP) plasma level, as the most sensitive indicator of NO bioactivity [14, 38]. Additionally, the blood pressure alterations associated with the consumption of beetroot juice and beetroot-enriched bread were correlated with urinary $\mathrm{NO}_{3} / \mathrm{NO}_{2}$ levels [50]. In a similar instance, there is a considerable trend between the changes in SBP, plasma $\mathrm{NO}_{2}$, the reduction of peak and increase of blood pressure and plasma $\mathrm{NO}_{2}[40]$.

The $\mathrm{NO}_{3}$-mediated hypotensive effect of beetroot is highlighted by the elevation of XOR enzyme expression level and XOR-dependent $\mathrm{NO}_{2}$ reductase activity postingestion of beetroot juice, and the promised hypotensive effect is disrupted by allopurinol, an XOR 
Table 3 Acute effects of beetroot on blood pressure and vascular function

\begin{tabular}{|c|c|c|c|c|c|}
\hline Author & Study population & Study Design & $\begin{array}{l}\text { Sample } \\
\text { size }\end{array}$ & $\begin{array}{l}\text { Dose of beetroot and its corresponding } \mathrm{NO}_{3} \\
\text { content }\end{array}$ & Findings \\
\hline $\begin{array}{l}\text { Webb et al. } \\
{[14]}\end{array}$ & Healthy subjects & $\begin{array}{l}\text { Randomized, open- } \\
\text { label crossover }\end{array}$ & 14 & $\begin{array}{l}\text { Consumption of } 500 \mathrm{~mL} \text { beetroot juice }(\sim 1395 \\
\left.\mathrm{mg} \mathrm{NO}_{3}\right)\end{array}$ & $\downarrow$ Both SBP and DBP \\
\hline $\begin{array}{l}\text { Joris et al. } \\
{[34]}\end{array}$ & $\begin{array}{l}\text { Overweight and } \\
\text { obese men }\end{array}$ & $\begin{array}{l}\text { Randomized } \\
\text { crossover }\end{array}$ & 20 & $\begin{array}{l}\text { Consumption of } 140 \mathrm{~mL} \text { beetroot juice }(\sim 420 \\
\left.\mathrm{mg} \mathrm{NO}_{3}\right) \text { vs. } \mathrm{NO}_{3} \text {-depleted beetroot juice }\end{array}$ & $\begin{array}{l}\text { Improve postprandial } \\
\text { endothelial function }\end{array}$ \\
\hline $\begin{array}{l}\text { Hobbs et al. } \\
\text { [35] }\end{array}$ & Healthy adults & $\begin{array}{l}\text { Randomized, open- } \\
\text { label, } \\
\text { controlled crossover }\end{array}$ & 23 & $\begin{array}{l}\text { Daily consumption of } 200 \mathrm{~g} \text { beetroot bread } \\
\text { (contains } 100 \mathrm{~g} \text { beetroot } \sim 70 \mathrm{mg} \mathrm{NO} \text { ) vs. } 200 \mathrm{~g} \\
\text { white bread }(<0.6 \mathrm{mg} \mathrm{NO} \text { ) }\end{array}$ & $\begin{array}{l}\uparrow \text { Endothelium- } \\
\text { independent vasodilation } \\
\downarrow D B P\end{array}$ \\
\hline $\begin{array}{l}\text { Hobbs et al. } \\
{[36]}\end{array}$ & Healthy adults & $\begin{array}{l}\text { Randomized, } \\
\text { controlled, single- } \\
\text { blind, cross-over }\end{array}$ & 32 & $\begin{array}{l}\text { Consumption of } 500 \mathrm{~g} \mathrm{low}-\mathrm{NO}_{3}\left(<3.1 \mathrm{mg} \mathrm{NO} \mathrm{NO}_{3}\right) \\
\text { mineral water (as control), } 100 \mathrm{~g} \text { beetroot } \\
\text { juice+ } 400 \mathrm{~g} \text { water }\left(\sim 142 \mathrm{mg} \mathrm{NO} \mathrm{NO}_{3}\right), 250 \mathrm{~g} \text { beet- } \\
\text { root juice+ } 250 \mathrm{~g} \text { water }\left(\sim 465 \mathrm{mg} \mathrm{NO} \mathrm{NO}_{3}\right) \text { or } 500 \\
\mathrm{~g} \text { beetroot juice }\left(\sim 706 \mathrm{mg} \mathrm{NO} \mathrm{NO}_{3}\right)\end{array}$ & $\begin{array}{l}\downarrow \text { Both SBP and DBP in a } \\
\text { dose-dependent manner }\end{array}$ \\
\hline $\begin{array}{l}\text { Hobbs et al. } \\
{[36]}\end{array}$ & Healthy adults & $\begin{array}{l}\text { Randomized, } \\
\text { controlled, single- } \\
\text { blind, cross-over }\end{array}$ & 32 & $\begin{array}{l}\text { Consumption of } 200 \mathrm{~g} \text { red beetroot- and white } \\
\text { beetroot-enriched breads (contains } 100 \mathrm{~g} \text { red- } \\
\text { or white-beetroot } \sim 112 \text { and } 99 \mathrm{mg} \mathrm{NO} \text {, re- } \\
\text { spectively) vs. white bread }\left(<3.1 \mathrm{mg} \mathrm{NO}_{3} \text { ) }\right.\end{array}$ & $\downarrow \mathrm{SBP}$ and DBP \\
\hline $\begin{array}{l}\text { Hughes } \\
\text { et al. [37] }\end{array}$ & $\begin{array}{l}\text { Healthy young and } \\
\text { old adults }\end{array}$ & $\begin{array}{l}\text { Randomized, } \\
\text { controlled, double- } \\
\text { blind, cross-over }\end{array}$ & 26 & $\begin{array}{l}\text { Consumption of } 500 \mathrm{~mL} \text { beetroot juice }(\sim 583 \\
\left.\mathrm{mg} \mathrm{NO}_{3}\right)\end{array}$ & $\begin{array}{l}\downarrow \text { Peripheral and aortic BP } \\
\text { in both young and older } \\
\text { adults } \\
\downarrow \text { Aortic wave reflection } \\
\text { (assessed by aortic } \\
\text { augmentation index) only } \\
\text { in young adults }\end{array}$ \\
\hline $\begin{array}{l}\text { Vanhatalo } \\
\text { et al. [30] }\end{array}$ & Healthy adults & $\begin{array}{l}\text { Randomized, } \\
\text { controlled, double- } \\
\text { blind, cross-over }\end{array}$ & 8 & $\begin{array}{l}\text { Consumption of } 500 \mathrm{~mL} \text { beetroot juice ( } 322 \\
\mathrm{mg} \mathrm{NO}_{3} \text { ) vs. } 500 \mathrm{~mL} \text { low-calorie juice }\end{array}$ & $\downarrow \mathrm{SBP}$ and DBP \\
\hline $\begin{array}{l}\text { Kapil et al. } \\
{[38]}\end{array}$ & Healthy adults & $\begin{array}{l}\text { Randomized, double- } \\
\text { blind, cross-over }\end{array}$ & 35 & $\begin{array}{l}\text { Consumption of } 250 \mathrm{~mL} \text { beetroot juice }(\sim 340 \\
\left.\mathrm{mg} \mathrm{NO}_{3}\right) \text { vs. } 250 \mathrm{~mL} \text { water }\end{array}$ & $\begin{array}{l}\downarrow \text { SBP, prevented } \\
\text { endothelial dysfunction } \\
\text { caused by ischemia } \\
\text { reperfusion }\end{array}$ \\
\hline $\begin{array}{l}\text { Kemmner } \\
\text { et al. [39] }\end{array}$ & $\begin{array}{l}\text { patients with chronic } \\
\text { kidney disease }\end{array}$ & $\begin{array}{l}\text { Randomized open- } \\
\text { label cross-over }\end{array}$ & 17 & $\begin{array}{l}\text { Consumption of } 30 \mathrm{~g} \text { beetroot powder } \\
\left.\text { dispended in } 200 \mathrm{~mL} \text { tap water }(\sim 300 \mathrm{mg} \mathrm{NO})_{3}\right) \\
\text { vs. } 200 \mathrm{~mL} \text { tap water }\end{array}$ & $\begin{array}{l}\downarrow \text { Both } \mathrm{SBP} \text { and } \mathrm{DBP}, \downarrow \\
\text { arterial } \mathrm{BP}, \downarrow \text { renal resistive } \\
\text { index }\end{array}$ \\
\hline $\begin{array}{l}\text { Ghosh et al. } \\
\text { [40] }\end{array}$ & Hypertensive adults & $\begin{array}{l}\text { Randomized open- } \\
\text { label crossover }\end{array}$ & 30 & $\begin{array}{l}\text { Consumption of } 250 \mathrm{~mL} \text { beetroot juice }(\sim 217 \\
\left.\mathrm{mg} \mathrm{NO}_{3}\right) \text { vs. } 250 \mathrm{~mL} \text { low } \mathrm{NO}_{3} \text { water }(<4.3 \mathrm{mg} \\
\left.\mathrm{NO}_{3}\right)\end{array}$ & $\begin{array}{l}\downarrow \text { Both } \mathrm{SBP} \text { and } \mathrm{DBP}, \\
\downarrow \text { pulse wave velocity } \\
\uparrow \text { Erythrocytic } \mathrm{XOR} \\
\text { expression and } \mathrm{XOR}- \\
\text { dependent } \mathrm{NO}_{2} \text { reductase } \\
\text { activity }\end{array}$ \\
\hline $\begin{array}{l}\text { Velmurugan } \\
\text { et al. [33] }\end{array}$ & $\begin{array}{l}\text { patients with } \\
\text { hypercholesterolemia }\end{array}$ & $\begin{array}{l}\text { Randomized, double- } \\
\text { blind, placebo- } \\
\text { controlled }\end{array}$ & 69 & $\begin{array}{l}\text { Consumption of } 250 \mathrm{~mL} \text { beetroot juice }(\sim 370 \\
\left.\mathrm{mg} \mathrm{NO}_{3}\right) \text { vs. } \mathrm{NO}_{3} \text {-depleted beetroot juice }\end{array}$ & $\begin{array}{l}\downarrow \text { SBP } \\
\uparrow \text { Flow mediated dilation, } \\
\downarrow \text { pulse wave velocity, } \downarrow \\
\text { augmentation index }\end{array}$ \\
\hline $\begin{array}{l}\text { Berry et al. } \\
\text { [41] }\end{array}$ & COPD patients & $\begin{array}{l}\text { Randomized, single- } \\
\text { blind, crossover }\end{array}$ & 15 & $\begin{array}{l}\text { Consumption of } 140 \mathrm{ml} \text { beetroot juice }(\sim 480 \\
\left.\mathrm{mg} \mathrm{NO}_{3}\right) \text { vs. } \mathrm{NO}_{3} \text {-depleted beetroot juice }(<1 \\
\left.\mathrm{mg} \mathrm{NO} \mathrm{N}_{3}\right)\end{array}$ & $\downarrow$ Resting SBP and DBP \\
\hline $\begin{array}{l}\text { Coles et al. } \\
\text { [42] }\end{array}$ & Healthy adults & $\begin{array}{l}\text { Rndomized double- } \\
\text { blind,, placebo- } \\
\text { controlled, crossover }\end{array}$ & 30 & $\begin{array}{l}\text { Consumption of } 140 \mathrm{ml} \text { beetroot juice }(\sim 465 \\
\mathrm{mg} \mathrm{NO}_{3} \text { ) vs. apple juice }\end{array}$ & $\downarrow \mathrm{SBP}$ in men \\
\hline $\begin{array}{l}\text { Curtis et al. } \\
\text { [43] }\end{array}$ & COPD patients & $\begin{array}{l}\text { Randomized double- } \\
\text { blind, placebo- } \\
\text { controlled, cross-over } \\
\text { single dose }\end{array}$ & 21 & $\begin{array}{l}\text { Consumption of } 140 \mathrm{ml} \text { beetroot juice }(\sim 800 \\
\left.\mathrm{mg} \mathrm{NO}_{3}\right) \text { vs. } \mathrm{NO}_{3} \text {-depleted beetroot juice }\end{array}$ & $\downarrow$ Resting DBP \\
\hline
\end{tabular}

NO Nitric Oxide, DBP Diastolic Blood Pressure, SBP Systolic Blood Pressure, COPD Chronic Obstructive Pulmonary Disease

inhibitor [40]. The reduction of blood pressure following beetroot consumption is believed to suppress and interrupt the salivary $\mathrm{NO}_{3}$ uptake. Various factors such as smoking (increasing salivary thiocyanate) [24], use of antibacterial mouthwash (reduction/ removal of oral NO3- reducing bacteria) $[47,53-55]$ and inorganic iodide supplementation (salivary $\mathrm{NO}_{3}$ uptake reduction) [20] interfere with $\mathrm{NO}_{3}$ enter-salivary circulation, a rate- 


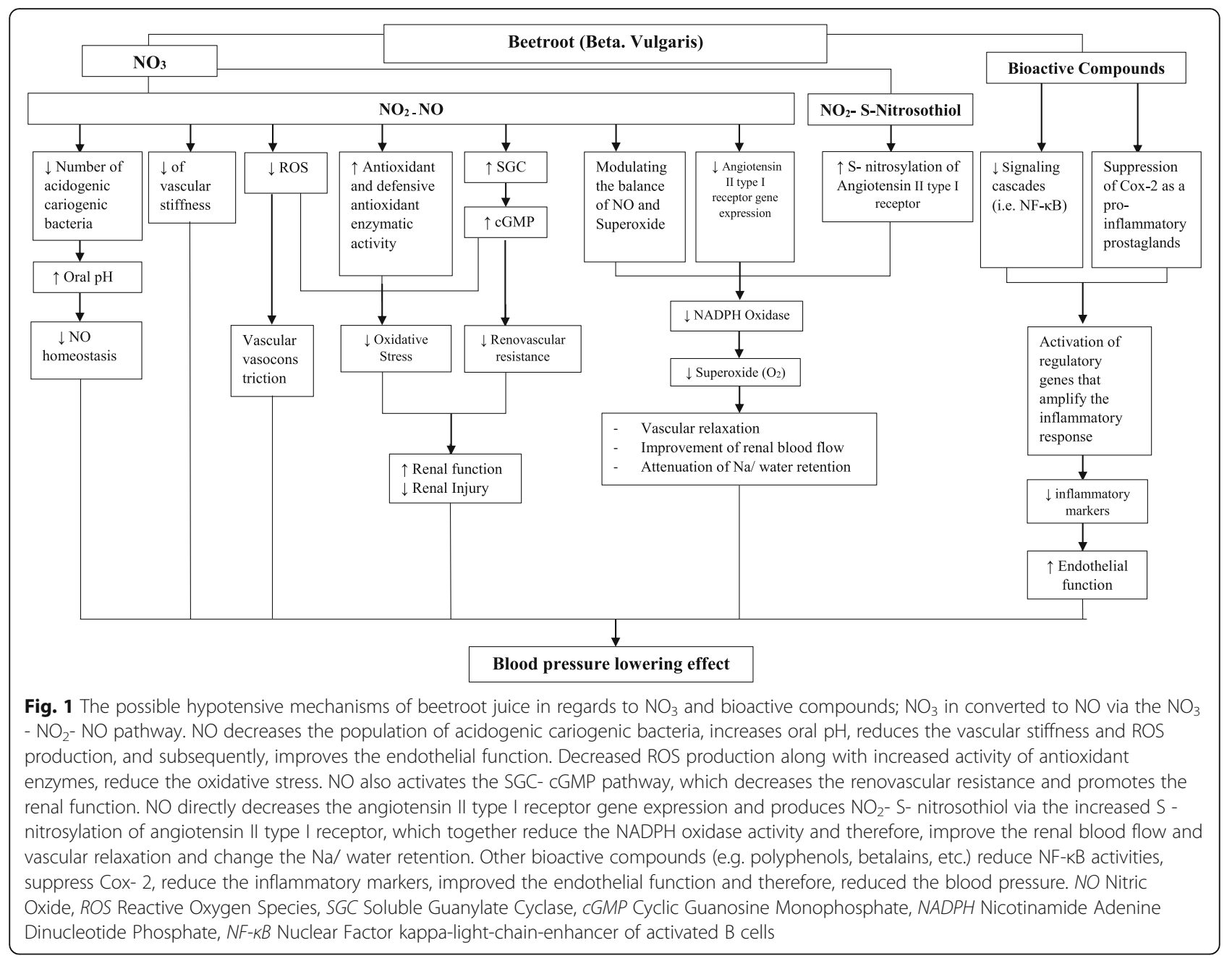

limiting step for dietary $\mathrm{NO}_{3}$ metabolism. Evidences suggest this procedure to consequently disturb cardioprotective aspects of dietary $\mathrm{NO}_{3}$.

Altogether, based on the current prevailing perception, $\mathrm{NO}_{3}$ and its subsequent $\mathrm{NO}$ product are mainly responsible for cardio-protective and hypotensive effects of beetroot supplements; while so, additive or synergistic effects of other bioactive compounds such as vitamin C, polyphenols and carotenoids should not be neglected.

\section{Effects of beetroot on glucose and insulin homeostasis}

The potential hypoglycemic effect of beetroot juice across healthy individuals and patients with various disorders have been studied previously, out of which $5 \mathrm{hu}$ man and 2 animal studies were investigated in this review (Table 4). Significant reduction of blood glucose level and the positive impact on the glycemic and insulin responses were reported $(P$-value $=0.004)$, among which multiple mechanisms and highlighted role of bioactive compounds (e.g. polyphenols, flavonoids, nitrate etc.) were critical. Due to the contribution of the lipid profile as a complementary factor in the incidence of glycemic abnormalities, this topic was also briefly evaluated in conjunction within this section.

An observational study was conducted on the phytochemical constituent of $225 \mathrm{~mL}$ beetroot juice among 16 healthy adults and related postprandial timing. Three samples of $50 \mathrm{~g}$ available carbohydrates, in the form of beetroot juice were administered, with lemon in the first sample, sucrose, fructose, glucose in the second sample (matched control drink) and glucose in the third sample, respectively. This assessment found a positive correlation on both glycemic and insulin responses in the first sample over the two beverages. The glycemic response post- beetroot juice consumption via the first and second drinks was shown to be significantly lower than the third drink. Considerably lower insulin response was elicited between beetroot juice and the control drink that remained non- significant. In this respect, it is suggested that polyphenol- rich beetroot juice might be responsible for the late rise in the early phases of postprandial glucose or insulin responses [48]. 
Table 4 Effects of beetroot on glucose-insulin homeostasis, lipid profiles and oxidative stress

\begin{tabular}{|c|c|c|c|c|c|c|}
\hline Author & Study population & Study design & $\begin{array}{l}\text { Sample } \\
\text { size }\end{array}$ & $\begin{array}{l}\text { Duration } \\
\text { (days) }\end{array}$ & Dose of beetroot and $\mathrm{NO}_{3}$ & Findings \\
\hline $\begin{array}{l}\text { Shepherd } \\
\text { et al. [81] }\end{array}$ & $\begin{array}{l}\text { Healthy young and } \\
\text { old adults }\end{array}$ & $\begin{array}{l}\text { Randomized } \\
\text { double- blind, } \\
\text { placebo } \\
\text { controlled, cross- } \\
\text { over }\end{array}$ & 31 & - & $\begin{array}{l}\text { Consumption of } 140 \mathrm{~mL} \text { beetroot } \\
\left.\text { juice }(\sim 738 \mathrm{mg} \mathrm{NO})_{3}\right) \text { vs. } \mathrm{NO}_{3^{-}} \\
\text {depleted beetroot juice }\end{array}$ & $\begin{array}{l}\text { No effect on plasma glucose, C- } \\
\text { peptide, or incretin concentration }\end{array}$ \\
\hline $\begin{array}{l}\text { Fuchs et al. } \\
{[82]}\end{array}$ & $\begin{array}{l}\text { Obese, insulin- } \\
\text { resistant patients }\end{array}$ & $\begin{array}{l}\text { Randomized } \\
\text { double- blind, } \\
\text { controlled }\end{array}$ & 16 & - & $\begin{array}{l}\text { Consumption of } 100 \mathrm{~mL} \text { beetroot } \\
\text { juice }\left(\sim 300 \mathrm{mg} \mathrm{NO}_{3}\right) \text { vs. water }\end{array}$ & $\begin{array}{l}\text { No effect on postprandial } \\
\text { glucose and insulin response }\end{array}$ \\
\hline $\begin{array}{l}\text { Wootton- } \\
\text { Beard et al. } \\
{[48]}\end{array}$ & Healthy adults & $\begin{array}{l}\text { Randomized } \\
\text { single- blind, } \\
\text { placebo } \\
\text { controlled, cross- } \\
\text { over }\end{array}$ & 16 & - & $\begin{array}{l}\text { Consumption of } 225 \mathrm{~mL} \text { beetroot } \\
\text { juice }\left(\sim 990 \mathrm{mg} \mathrm{NO}_{3}\right) \text { vs. control } \\
\text { beverage matched for } \\
\text { macronutrient content }\end{array}$ & $\begin{array}{l}\downarrow \text { Postprandial insulin response in } \\
\text { the early phase }(0-60 \mathrm{~min}) \\
\downarrow \text { Glucose response in the } 0-30 \\
\text { min phase }\end{array}$ \\
\hline $\begin{array}{l}\text { Gilchrist } \\
\text { et al. [28] }\end{array}$ & T2DM patients & $\begin{array}{l}\text { Randomized } \\
\text { double- blind, } \\
\text { placebo } \\
\text { controlled, cross- } \\
\text { over }\end{array}$ & 27 & 14 & $\begin{array}{l}\text { Daily consumption of } 250 \mathrm{~mL} \\
\text { beetroot juice }(\sim 500 \mathrm{mg} \mathrm{NO}) \text { vs. } \\
\mathrm{NO}_{3} \text {-depleted beetroot juice }\end{array}$ & No effect on insulin resistance \\
\hline $\begin{array}{l}\text { Kerley et al. } \\
{[27]}\end{array}$ & $\begin{array}{l}\text { Controlled and } \\
\text { uncontrolled } \\
\text { hypertensive patients }\end{array}$ & Pilot study & 19 & 14 & $\begin{array}{l}\text { Daily consumption of } 140 \mathrm{ml} \\
\text { beetroot juice }\left(\sim 800 \mathrm{mg} \mathrm{NO}_{3}\right)\end{array}$ & $\begin{array}{l}\downarrow \text { Serum LDL-C in uncontrolled } \\
\text { patients }\end{array}$ \\
\hline $\begin{array}{l}\text { Asgary et al. } \\
{[29]}\end{array}$ & $\begin{array}{l}\text { Hypertensive un- } \\
\text { treated adults }\end{array}$ & $\begin{array}{l}\text { Randomized } \\
\text { crossover pilot } \\
\text { study }\end{array}$ & 24 & 14 & $\begin{array}{l}\text { Daily consumption of } 250 \mathrm{~mL} \\
\text { beetroot juice vs. } 250 \mathrm{~g} \text { cooked } \\
\text { beetroot }\end{array}$ & $\begin{array}{l}\text { No effect on blood glucose } \\
\downarrow \text { Serum hs-CRP, IL- } 6 \text { and TNF-a } \\
\uparrow \text { TAC in beetroot juice group } \\
\downarrow \text { Non-HDL-C, total cholesterol } \\
\text { and LDL-C in beetroot juice } \\
\text { group }\end{array}$ \\
\hline $\begin{array}{l}\text { Singh et al. } \\
{[80]}\end{array}$ & Healthy adults & $\begin{array}{l}\text { Randomized, } \\
\text { cross- over }\end{array}$ & 30 & 15 & $\begin{array}{l}\text { Daily consumption of } 500 \mathrm{~mL} \\
\text { beetroot juice }\end{array}$ & $\begin{array}{l}\uparrow \mathrm{HDL}-\mathrm{C}, \downarrow L \mathrm{LDL}-\mathrm{C}, \uparrow \text { Total antioxi- } \\
\text { dant capacity and serum vitamin } \\
\text { C levels }\end{array}$ \\
\hline $\begin{array}{l}\text { Kapil et al. } \\
\text { [32] }\end{array}$ & $\begin{array}{l}\text { Hypertensive older } \\
\text { adults }\end{array}$ & $\begin{array}{l}\text { Randomized, } \\
\text { phase 2, double- } \\
\text { blind, placebo- } \\
\text { controlled study }\end{array}$ & 68 & 28 & $\begin{array}{l}\text { Daily consumption of } 250 \mathrm{~mL} \\
\text { beetroot juice }(\sim 450 \mathrm{mg} \mathrm{NO} \text { ) vs. } \\
\mathrm{NO}_{3} \text {-depleted beetroot juice }\end{array}$ & $\begin{array}{l}\text { No effect on fasting glucose, } \\
\text { glycated haemoglobin, serum } \\
\text { creatinine, sodium and } \\
\text { potassium, or lipid profile }\end{array}$ \\
\hline $\begin{array}{l}\text { Velmurugan } \\
\text { et al. [33] }\end{array}$ & $\begin{array}{l}\text { patients with } \\
\text { hypercholesterolemia }\end{array}$ & $\begin{array}{l}\text { Randomized, } \\
\text { double-blind, } \\
\text { placebo-controlled }\end{array}$ & 69 & 42 & $\begin{array}{l}\text { Daily consumption of } 250 \mathrm{~mL} \\
\text { beetroot juice }\left(\sim 370 \mathrm{mg} \mathrm{NO} \mathrm{N}_{3}\right) \text { vs. } \\
\mathrm{NO}_{3} \text {-depleted beetroot juice }\end{array}$ & $\begin{array}{l}\text { No effect on oxidized LDL, hs- } \\
\text { CRP, and uric acid }\end{array}$ \\
\hline
\end{tabular}

NO Nitric Oxide, T2DM Type 2 Diabetes Mellitus, hs-CRP high-sensitivity C-Reactive Protein, IL-6 Interleukin-6, TNF- $a$ Tumor Necrosis Factor-alpha, HDL-C High Density Lipoprotein-Cholesterol, LDL-C Low Density Lipoprotein- Cholesterol

Collected data from a recent study on 30 healthy participants outlined further decreasing trend of blood glucose level by $34.5 \%$ following longer-term ingestion of a $10 \%$ beetroot juice solution [48] within 4 weeks, comparing to the baseline and washout period; whereas such difference was not present within 2 weeks of the interventional phase. With significant assimilation to the hypotensive effect, it can be said that persistent consumption of beetroot juice might be necessary on the maintenance of sustainable impacts of blood glucose and insulin responses [49].

The administration of $270 \mathrm{~mL}$ beetroot juice among healthy adults in a randomized cross-over study, suspended the postprandial glycemic response and lowered the sustainability and peak of blood glucose level; therefore in contrast to a sugar-matched control drink, appeared useful [56].
Beals et al. have discussed the augmenting interference of concurrent dietary fiber-rich- beetroot juice and $25 \mathrm{~g}$ of glucose ( $75 \mathrm{~g}$ total carbohydrate load) among obese and non-obese individuals with glucose tolerance. Participants were supplemented with 500 $\mathrm{mL}$ beetroot solution $(17 \mathrm{mmol}$ nitrate and $25 \mathrm{~g}$ glucose) at baseline, glucose at time laps of $5,45,60$ and $90 \mathrm{~min}$, glucose solution and insulin at 10, 20,30 and $120 \mathrm{~min}$. It was eventuated that the inhibition of nitrate reductase activity did not only reduce the desire of metabolic responses to beetroot juice combined with glucose but also promoted insulin resistance ( $=0.009)$ and concealed insulin sensitivity within obese individuals. Unlikely, the co-ingestion of glucose and beetroot juice led to a higher elevation of blood glucose concentration in obese than nonobese adults at 60 and $90 \mathrm{~min}(=0.004)$. It was, 
therefore, obtained that obese adults with a higher risk of developing insulin resistance, may benefit from nitrate-rich foods [57].

Among studies compatible with the blood-glucoselowering effect of Beta vulgaris in this review, multiple mechanisms were suggested to be responsible (Fig. 2). Some papers emphasized the critical role of bioactive compounds $[48,58]$ including the action of ethanol via an ethanolic extraction of beetroot juice (EEBT) [59]. The nitrite- nitrate pathway, taking place in the oral cavity by the commensal bacteria, was also introduced [57]. Other mechanisms are including the modification of intracellular signal transduction as a major mechanism of reducing blood glucose by foods and hormonal activities, inhibition of $\alpha$-amylase and $\alpha$-glucosidase and increase in paraoxonase 1 (PON1) [60]. The increasing trend of serum cortisol level post- beetroot consumption, as a stress hormone and leading factor in the elevation of gluconeogenesis, is coupled with the reduced glucose concentration, as well. This phenomenon can be related to either the Adrenocorticotropic hormone (ACTH) secretion or the mode of action at the adrenal cortex level [49]. Therefore, the intake of beetroot juice decreased the blood glucose level comparing to the control and placebo beverages, the reason of which is postulated to be regarding the polyphenol, betanins and neobetanin, as a betanin degradation product, ethanol content, nitrite- nitrate pathway or the inhibition of hormonal reductase activity.
In addition to the glycemic controlling properties of beetroot juice, some articles highlighted the beneficial effect of this beverage on lipid profile and its parameters (TC, TG, HDL, and LDL), which is directly related to the incidence of T2DM. One randomized, double- blind study in this regard investigated the acute, $2 \mathrm{~h}$ postconsumption (2HPP) effect of beetroot juice on plasma glucose and lipid status. Among the related parameters TG was only revealed to be notably higher in the intervention group at pre-treatment level. While so, the 2HPP was shown to be lower than that preadministration of beetroot juice comparing to the control. The lipid profile parameters decreased at posttreatment level, and all parameters but HDL had significantly lower values than those in the control group. It, however, remained upon discussion whether these implications are to any extent related to $\alpha$ - lipoic acid and antioxidant content of Beta vulgaris or other factors involved [58].

An animal study on the blood-glucose-lowering effect of beetroot juice extended our knowledge in an STZ (Streptozotocin) - induced diabetic rat model. In this study, animals have been treated with either $400 \mathrm{mg} / \mathrm{kg}$ p.o. (orally) Ethanolic Extract of Beetroot Juice or $5 \mathrm{mg} /$ Kg p.o. Glibenclamide. It was implied that the effect of Glibenclamide on TG and cholesterol level was comparable with that in EEBT- treated animals. In fact, administration of EEBT potentially reduced the serum levels of cholesterol and TG in comparison to diabetic control

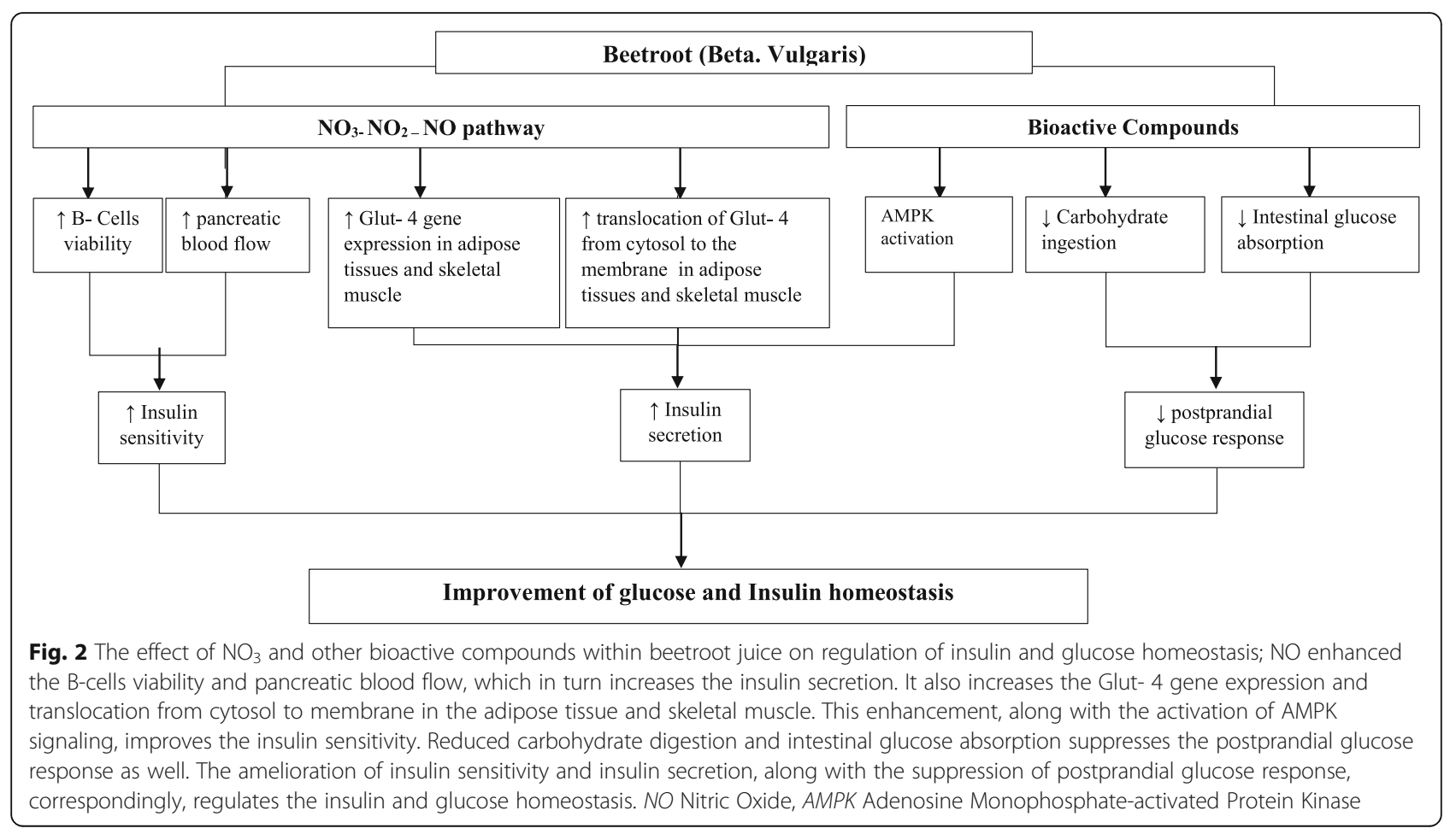


rats, which is hypothesized to be regarding a long exposure (21 days) to EEBT solution [59].

Altogether, these studies raised evidence in favor of blood glucose lowering effect of beetroot and beetroot juice in particular. It can be implied that beetroot juice is able to effectively lessen the impact of insulin resistance in a drug- comparable manner.

\section{Effects of beetroot on microbiome}

Thus far, data and information regarding the impact of Beta vulgaris on gut microbiome and salivary microflora is limited, yet the association with metabolic dysfunction cannot be neglected. Within this context it was primarily indicated that dietary $\mathrm{NO}_{3}$ supplementation could alter the salivary microbiome, an outcome that has been perused through investigation of 6 human and 7 animal studies in this review.

Vanhatalo et al. have performed one of the leading human studies on the connection between the nitrateresponsive oral microbiome and nitric oxide (NO) homeostasis, which have revealed a positive relationship between nitrate- nitrite pathway on microbiome action and salivary flow rate. Nevertheless, it is still in doubt, how the abundance of known $\mathrm{NO}_{3}$ - reducing bacteria such as Fusobacterium nucleatum, Prevotella melaninogenica and Leptorichia buccalis affects nitrate response. NO biomarkers, including the blood pressure and arterial stiffness, have been used to express the results. The $\mathrm{NO}_{3}$ and $\mathrm{NO}_{2}$ values were seen to be significantly higher in the beetroot juice supplemented group than the control. The results have also explained no considerable SBP and DBP modulations comparing to the baseline, notwithstanding a non- significant difference to be present among older subjects, due to the higher $\mathrm{NO}_{2}$ concentration in that group following beetroot juice consumption. The high baseline abundance of Fusobacterium nucleatum subsp. vincentii and nucleatum among other oral bacteria reduced blood pressure as a physiological response to beetroot juice supplementation as the phyla that possess a non-significant lower availability following beetroot juice consumption comparing to placebo [61]. Based on this article, the chronic ingestion of inorganic $\mathrm{NO}_{3}$ not only increases a proportion of the oral microbiome including Bacteroidetes, Firmicutes and Fusobacteria, but also serves to change the relative abundance of a few, but not all, $\mathrm{NO}_{3}$ - reducers. This alteration is positive in Neisseria and Rothia reducers, due to the high NO bioavailability, as a probable cardiovascular health promoter, and negative among Prevotella and Veillonella. Authors concluded that dietary $\mathrm{NO}_{3}$ supplementation could alter the salivary microbiome in young and old normotensive individuals [61].

The consumption of nitrate-rich Beta vulgaris also increase the consequent rate of $\mathrm{NO}$ bioconversion and mean $\mathrm{pH}$ (from 7.0 to 7.5). Assuming bioconversion to occur in the mouth [62], it is suggestive that this process may play a critical role in host defense [63, 64], lower prevalence of metabolic dysfunction and caries in the oral cavity through acidification- preventing properties of human saliva and therefore, shift the composition of the microbiome [62]. It is well established that the administration of $\mathrm{NO}_{3}$ supplementation as beetroot juice enhances cardio-protective and cardio-enhancing properties [65-67]. In one study, 46 healthy participants were treated with $100 \mathrm{~mL}$ of beetroot juice or placebo, (each corresponding to $400 \mathrm{mg}$ and $2 \mathrm{mg} \mathrm{NO} \mathrm{N}_{3)}$. Collected data indicated that the salivary nitrate concentration among beetroot juice and placebo consuming groups both had elevated, yet the range in beetroot juice consumers reached more significant. Consequently, it was highlighted that the baseline value reached the maximum amount within day 8 of beetroot juice and day 15 of placebo consumption [62].

Since the NO bioconversion is of high importance in the metabolic function, the second assessment was performed on the total NO bioavailability and bioconversions in the mouth, as a commensal microfloradependent procedure. Based on the measurements, the ultimate levels were detected within the first $2 \mathrm{~h}$ subsequent to each drink, comparing to the basal mean levels of salivary NO. NO concentration was found to decline among the beetroot juice consuming group and back to basal levels straight after the juice consumption period, suggesting consistent ingestion for the determination of antimicrobial effect and other biological functions of $\mathrm{NO}$ to be required [62].

The fermentation of beetroot juice has recently sparked interest as an evolving strategy that is being investigated across several human and animal subjects. One of such efforts is a study on Lactic acid bacteria fermentation, where three phylus of Lactobacillus plantarum, Lactobacillus rhamnnosus, and Lactobacillus delbrueckii sb. were cultivated on pasteurized beetroot juice. The comparison of fresh and probiotic beetroot juice, presented a slight increase in the protein values from 3.74 to $3.77 \%$, the acidity of the samples from 0.49 to $0.78 \%$ and total antioxidant activity and capacity [68].

This conclusion was in agreement with a recent study among animal models, investigating the administration of lacto-fermented beetroot juice (FBJ) alone or along with M-nitroso-N-methyl urea (MNU- as a harmful factor). The results have shown Bifidobacterium to be the most stable microorganism that almost equally colonized the gut epithelium. It also indicated that the mutagen $\mathrm{MNU}$ is incapable of affecting microorganism adherence to the gut epithelium. MNU led to various outcomes depending on the bacterial phylus and the type of intervention [69]. 
Fresh and lacto-fermented beetroot juices are distinguished by the high anti-carcinogenic and antimutagenic potentials [70-72]. Betacyanin components of FBJ, betanidin and betanin overwhelms that in the fresh juice, which is consist of betanin as a dominating compound, instead of betanidin [73]. This study displayed an increase in the antioxidant capacity of blood serum in groups administered with FBJ [69].

The same author has studied the effect of probiotic Lactobacillus casei 0920 and Lactobacillus brevis 0944 fermented beetroot juice (beetroot juice as a lactic acid bacteria carrier). Accordingly, it was concluded that the consumption of fermented juice containing live lactic acid bacteria could positively change the count of intestinal microflora, its metabolic activity, and enzymes involved in the process of carcinogenesis including $\beta$ glucosidase, $\beta$-glucuronidase, and $\beta$-galactosidase. In other words, the daily administration of fermented beetroot juice reduced the enzymatic activity to $75.4,53.6$, and $59.5 \mathrm{U} / \mathrm{g}$, respectively. The activity of $\beta$ - glucuronidase was also decreased subsequent to the administration of 3.0 and $6 \mathrm{~mL}$ of the fermented beetroot juice per day (by 26 and 28\%, respectively) [74].

Therefore, it was elucidated that chronic and regular ingestion of fermented beetroot juice may lead to the sustaining intestinal microbial ecosystem and modifying the metabolic activity to reduce the risk of food intolerance related diseases [74].

\section{Effects of beetroot on kidney function}

Despite the positive hypertensive and hyperglycemic effect of beetroot juice, a limited number of studies have acknowledged the reno-protective properties associations with specific renal parameters. To address the key areas of this topic in our comprehensive review, 6 selective literatures, 3 human and 3 animal studies, were summarized and reported. Beetroot juice consumption and its ultimate outcomes in this section, appeared more beneficially among animal models.

In this regard, one and the main human study on stages 2 to 5 of Chronic Kidney Disease patients (CKD II-IV any degree of decrease in the renal function) by Kemmner et al., suggested the administration of nitrate donor beetroot juice to a nitrate load of $300 \mathrm{mg}$ across 9 patients to increase (NO) concentration and elevate the renal resistive index (RRI) as prognostic markers for cardiovascular mortality [39]. This outcome was more vivid among CKD patients that faced a reduction of renal function and elevation of arterial stiffness, with Glomerular Filtration Rate (GFR) values below normal of 90 $\mathrm{mL} / \mathrm{min} / \mathrm{m}^{2}$. This decreased value was primarily caused by hypertensive or diabetic nephropathy, both as causal factors or the subsequent results of the failure. Comparing to the control, the serum creatinine, GFR and serum potassium level did not alter significantly following beetroot juice ingestion, which in case of potassium, also remained about persistent comparing to placebo [39].

With that said, an animal intervention has investigated the beneficial contribution of either beetroot juice or nutraceutical beetroot juice in the treatment of Gentaciamin-nephrotoxicity- induced rats. It was suggested that beetroot juice with prophylactic perspectives actively supported the renal system to overcome the adverse effects of Gentamicin (GM)'s primary and secondary reactive metabolites, resulting from the toxicantinduced damage. Therefore, consumption of beetrootbased beverages depicted positive implications by increasing the level of Superoxide Dismutase (as a primary antioxidant enzyme), and Catalase (involved in a detoxification procedure), while decreasing $\mathrm{NO}$ (with a controversial role in renal system), and oxidative stress, all as renal tissue-specific markers. Similarly, urea and creatinine content have lowered, while the protein profile of beetroot- based beverage accelerated, due to the action of bioactive compounds like betacyanins and betaxanthin [75].

Several protective strategies have been introduced to hold effective reno-protective implications. The blood pressure lowering effect via the action of Guanylyl Cyclases and cGMP, and subsequent nitrate- nitrite pathway of the facultative bacteria [76], a nitrate- mediated reduction of renal oxidative stress via decreasing the $\mathrm{NADH}$ oxidase activity and angiotensin II receptor (signals that attenuate angiotensin II-mediated renal arteriolar contraction) $[77,78]$ are of all conclusions drawn to explain the mechanism of action.

An animal study investigated the advantage of betavulgaris ethanol extract (BVEE) with potent antioxidant, anti-inflammatory and reno-protective properties in the treatment of GM- induced nephrotoxicity, modulation of renal dysfunction, oxidative stress, inflammation and amelioration of histological damage in rats. The administration of BVEE and GM- treatment subsequently, substantiated a significant suppressing effect on the elevation of urea, uric acid, total protein and creatinine in a dose-dependent manner [79].

BVEE beverage ( 250 and $500 \mathrm{mg} / \mathrm{kg}$, p.o) was also suggested to be practical on kidney lipid peroxidation factors. The activity level of catalase, as an important antioxidant enzymes, was reduced by $27.97 \%$ following GM treatment, and notably increased by 83.92 and $92.62 \%$, respectively, following the administration of 250 and $500 \mathrm{mg} / \mathrm{kg}$ BVEE. Similar trend was present for NP- SH content (non- protein sulfhydryl- for the measurement of renal non- protein sulfhydryl); a reduction of $37.94 \%$ following $85 \mathrm{mg} / \mathrm{kg}$ GM treatment was present, comparing to 71 and $81.71 \%$ increase in 
250 and $500 \mathrm{mg} / \mathrm{kg}$ BVEE, respectively. The total protein content of GM treated animals was decreased by $71.46 \%$ in comparison with a dose dependent increase in pretreated groups of $250 \mathrm{mg} / \mathrm{kg}$ and $500 \mathrm{mg} / \mathrm{kg}$ BVEE by 37.35 and $43.74 \%$, respectively [79].

The data and findings here confirmed the ameliorating effect of Beta vulgaris as a beneficial additive treatment on kidney's functional parameters, reducing the progressive rate of renal disease, and subsequently mortality in high risk groups including hypertensive CKD and diabetic nephropathy patients. It however remains to be investigated whether the decreasing effect over RRI values and blood pressure is ascribed to supplementation with the vasodilator- dietary nitrate or potent antioxidant, anti-apoptosis and anti-inflammatory properties possess by betacyanin components including betanin and betanin. It is upon discussion that BVEE treatment improves the extent of structural damage and decreases inflammatory infiltration in renal tubules through the reduction of oxidative stress, inflammation, and apoptosis in the kidney.

\section{Potential drug interaction and adverse effects}

There is limited evidence in regards to the adverse effects and tolerance issues of beetroot juice and its components. Exclusive number of studies reported major negative implications associated with the consisting bioactive compounds, out of which, 5 studies were assessed in our review.

Beeturia, urea discoloration or excretion of red/ pink urine following beetroot ingestion occurs due to the presence of un-metabolized betalain pigments in the urine and has been reported in 10-14\% of Shepherd's study population [17]. It is a strong, though benign effect that had been stated by most of the participants of previous studies as well. In other words, short term and long term treatment with beetroot juice were well tolerated by the subjects. This is a confirmation on a safe administrating strategy of beetroot through acute and chronic phases [18].

It is partly evident that a 5 days administration of betalain- rich beetroot juice ( 25 and $100 \mathrm{mg} \cdot \mathrm{kg} \cdot \mathrm{bm}-1$ ), markedly inhibited NF- $\mathrm{kB}$ DNA-binding activity in renal damage- induced rats and significantly suppressed Cyclooxygenase 2 (Cox-2) expression in vitro by nearly 97\%. This revealed a more significant anti-inflammatory effect than many rival synthetic drugs including Ibuprofen, Vioxx and Celebrex [4]. It is also proven that a 28 days administration of beetroot juice $(250 \mathrm{mg}$ or 500 $\mathrm{mg} \cdot \mathrm{kg} \cdot \mathrm{bm}-1$ ), inhibits NF-kB DNA binding activity across nephrotoxic rats in a dose-dependent manner. Therefore, an alternative here to synthetically manufactured medications, including Non- steroidal anti- inflammatory drug (NSAIDs), is to shift towards natural resources and additional treatments [4].

The potential interaction of $\mathrm{NO}_{3}$ - rich beetroot juice with phosphodiesterase- 5 inhibitors and consequent severe hypotension, is another consideration. Beneficial properties of beetroot can be profoundly affected by medications imposing undesirable interaction with metabolism and the ultimate metabolic pathways of $\mathrm{NO}_{3} /$ $\mathrm{NO}_{2}$; as such, the hypotensive effect of orally ingested $\mathrm{NO}_{2}$ is proposed to be abolished by esomeprazole, a proton pump inhibitor [18].

Beetroot itself takes crucial part in drug metabolism and pharmacological treatment; the carotenoid content is said to be involved in Xenobiotic function and metabolism. The interference of Betalain with a broad spectrum of anti- inflammations properties and the proinflammatory signaling agent especially the Nuclear Factor-Kappa B (NF-kB) cascade is taken into account as an alternative of therapeutic medications with fewer adverse effects [4].

Cytochrome P450 (CYP450) is known to be an active transporter in drug metabolism. This hemeprotein, with potent vasoconstriction properties, and its metabolite 20-Hydroxyeicosatetraenoic acid (20-HETE) are critical in regulation of renal, pulmonary and cardiac function [80]. To the best of our knowledge, there are no studies in regards to the direct effect of beetroot and its byproducts on CYP450, however, NO, as an important beetroot component, was revealed to mediate the inflammatory- induced down- regulation of CYP450 and therefore, inhibit the conversion of CYP450 to 20-HETE. Also, active components including polyphenols, flavonoids and anthocyanins possess a similar inhibitory response in a comparable manner to other CYP450 inhibitors. Therefore, the food- drug and drug- food interactions along with the dose and duration of drug intake come back into focus.

Subsequently, it is important to ascertain the probable interactions between beetroot juice and various supplements of proven ergogenic effects such as caffeine, creatinine, $\beta$-alanine, and sodium bicarbonate, and assure the possible beneficial impacts [7].

With accordance to the high oxalic acid constitution of beetroot, comparing to other vegetables and fruits (400-600 mg/100 g fresh weight) [1], natural beetrootbased supplements, are not presently anticipating major negative health outcomes related to beetroot juice bioactive components. Therefore, it is unlikely to be a risk to human health in the short term.

Considering the public interest to ergogenic and cardio-protective effects of beetroot supplementation, future clinical studies are required to evaluate the longterm efficacy and safety of beetroot dietary intervention in health and disease states. 


\section{Conclusion}

Available data supported the health-promotional properties of beetroot and its byproducts, as a potential therapeutic treatments for various metabolic disorders including hypertension, diabetes, insulin resistance and kidney dysfunction. In human studies to date, beetroot supplementation has been reported to reduce systolic and diastolic blood pressure, inhibit platelet aggregation, improve vascular and endothelial function, reduce blood glucose and improve insulin homeostasis, and possess reno-protective properties. Beetroot contains high concentration of phytochemicals and essential nutrients and is abundant in inorganic $\mathrm{NO}_{3}$. Bioactive compounds are believed to play crucial roles within the mechanistic pathways and be responsible for the promising clinical effects.

\section{Abbreviations}

aPWV: Aortic Pulse Wave Velocity; BMI: Body Mass Index; BP: Blood Pressure; CKD: Chronic Kidney Disease; CYP450: Cytochrome P450; DBP: Diastolic Blood Pressure; FBS: Fasting Blood Sugar; HDL: High-Density Lipoprotein; HETE-20: 20-Hydroxyeicosatetraenoic acid; LDL: Low-Density Lipoprotein; $\mathrm{NO}$ : Nitric oxide; $\mathrm{NO}_{2}$ : Nitrite; $\mathrm{NO}_{3}$ : Nitrate; SBP: Systolic Blood Pressure; T2DM: Type 2 Diabetes Mellitus; TC: Total Cholesterol; TG: Triglyceride

\section{Acknowledgements}

The authors would like to express their appreciation to the staff of the Research Institute for Endocrine Science.

\section{Authors' contributions}

PM designed the study. ZG, ZH and ZB collected the data from previous studies, ZG, PM and ZH wrote the manuscript, FA corrected the manuscript. All authors read and approved the final manuscript.

\section{Funding}

This work was not supported by any funding agency.

Availability of data and materials

Not Applicable.

\section{Ethics approval and consent to participate}

Not Applicable.

\section{Consent for publication}

Not Applicable.

\section{Competing interests}

The authors declare that they have no competing interests.

\section{Author details}

${ }^{1}$ Nutrition and Endocrine Research Center, Research Institute for Endocrine Sciences, Shahid Beheshti University of Medical Sciences, Tehran, No. 24, Sahid-Erabi St, Yemen St, Chamran Exp, Tehran, Iran. Endocrine Research Center, Research Institute for Endocrine Sciences, Shahid Beheshti University of Medical Sciences, Tehran, Iran.

\section{Received: 25 August 2019 Accepted: 23 December 2019}

Published online: 07 January 2020

\section{References}

1. Wruss J, Waldenberger G, Huemer S, Uygun P, Lanzerstorfer P, Müller U, et al. Compositional characteristics of commercial beetroot products and beetroot juice prepared from seven beetroot varieties grown in Upper Austria. J Food Compos Anal. 2015;42:46-55.

2. Agency CFI. The Biology of Beta vulgaris L. (Sugar Beet). Canadian Food Inspection Agency; Canada: Government of Canada; 2012 [cited 2018].
Available from: http://www.inspection.gc.ca/plants/plants-with-novel-traits/ applicants/directive-94-08/biology-documents/beta-vulgaris-l-/eng/13307253 73948/1330725437349

3. Georgiev VG, Weber J, Kneschke E-M, Denev PN, Bley T, Pavlov Al. Antioxidant activity and phenolic content of Betalain extracts from intact plants and hairy root cultures of the red beetroot Beta vulgaris cv. Detroit dark red. Plant Foods Hum Nutr. 2010;65(2):105-11.

4. Clifford T, Howatson G, West D, Stevenson E. The potential benefits of red beetroot supplementation in health and disease. Nutrients. 2015;7(4):2801-22.

5. Domínguez R, Cuenca E, Maté-Muñoz J, García-Fernández P, Serra-Paya N, Estevan $M$, et al. Effects of beetroot juice supplementation on cardiorespiratory endurance in athletes. A systematic review. Nutrients. 2017:9(1):43

6. Chhikara N, Kushwaha K, Sharma P, Gat Y, Panghal A. Bioactive compounds of beetroot and utilization in food processing industry: a critical review. Food Chem. 2018;272:192-200.

7. Domínguez R, Maté-Muñoz JL, Cuenca E, García-Fernández P, Mata-Ordoñez F, Lozano-Estevan MC, et al. Effects of beetroot juice supplementation on intermittent high-intensity exercise efforts. J Int Soc Sports Nutr. 2018;15(1):2.

8. Baião D, Silva D, Mere Del Aguila E, Paschoalin V. Nutritional, Bioactive and Physicochemical Characteristics of Different Beetroot Formulations; 2017.

9. Singh B, Hathan BS. Chemical composition, functional properties and processing of beetroot-a review. Int J Sci Eng Res. 2014;5(1):679-84.

10. Morgado M, de Oliveira GV, Vasconcellos J, Monteiro ML, Conte-Junior C, Pierucci APTR, et al. Development of a beetroot-based nutritional gel containing high content of bioaccessible dietary nitrate and antioxidants. Int J Food Sci Nutr. 2016;67(2):153-60.

11. Guldiken B, Toydemir G, Nur Memis K, Okur S, Boyacioglu D, Capanoglu E. Home-processed red beetroot (Beta vulgaris L.) products: changes in antioxidant properties and bioaccessibility. Int J Mol Sci. 2016;17(6):858.

12. Kazimierczak R, Siłakiewicz A, Hallmann E, Srednicka-Tober D, Rembiałkowska E. Chemical composition of selected beetroot juices in relation to beetroot production system and processing technology. Notulae Botanicae Horti Agrobotanici Cluj-Napoca. 2016;44(2):491-8.

13. Holmes RP, Assimos DG. The impact of dietary oxalate on kidney stone formation. Urol Res. 2004;32(5):311-6.

14. Webb AJ, Patel N, Loukogeorgakis S, Okorie M, Aboud Z, Misra S, et al. Acute blood pressure lowering, vasoprotective, and antiplatelet properties of dietary nitrate via bioconversion to nitrite. Hypertension. 2008;51(3):784-90.

15. Varner AS. Modeling and optimization of the dehydration of beets for use as a value- added food ingredient; 2014.

16. Kumar Y. Beetroot: A Super Food. International Journal of Engineering Studies and Technical Approach March 2015; Volume 01, No.3.

17. Shepherd Al, Wilkerson DP, Dobson L, Kelly J, Winyard PG, Jones AM, et al. The effect of dietary nitrate supplementation on the oxygen cost of cycling, walking performance and resting blood pressure in individuals with chronic obstructive pulmonary disease: a double blind placebo controlled, randomised control trial. Nitric Oxide. 2015;48:31-7.

18. Keen JT, Levitt EL, Hodges GJ, Wong BJ. Short-term dietary nitrate supplementation augments cutaneous vasodilatation and reduces mean arterial pressure in healthy humans. Microvasc Res. 2015;98:48-53.

19. Kelly J, Fulford J, Vanhatalo A, Blackwell JR, French O, Bailey SJ, et al. Effects of short-term dietary nitrate supplementation on blood pressure, $\mathrm{O} 2$ uptake kinetics, and muscle and cognitive function in older adults. Am J Phys Regul Integr Comp Phys. 2012;304(2):R73-83.

20. Bailey SJ, Blackwell JR, Wylie LJ, Emery A, Taylor E, Winyard PG, et al. Influence of iodide ingestion on nitrate metabolism and blood pressure following short-term dietary nitrate supplementation in healthy normotensive adults. Nitric Oxide. 2017;63:13-20.

21. Bailey SJ, Winyard P, Vanhatalo A, Blackwell JR, Dimenna FJ, Wilkerson DP, et al. Dietary nitrate supplementation reduces the $\mathrm{O} 2$ cost of low-intensity exercise and enhances tolerance to high-intensity exercise in humans. J Appl Physiol (1985). 2009;107(4):1144-55.

22. Cermak NM, Res P, Stinkens R, Lundberg JO, Gibala MJ, van Loon LJ. No improvement in endurance performance after a single dose of beetroot juice. Int J Sport Nutr Exerc Metab. 2012;22(6):470-8.

23. Lansley KE, Winyard PG, Bailey SJ, Vanhatalo A, Wilkerson DP, Blackwell JR, et al. Acute dietary nitrate supplementation improves cycling time trial performance. Med Sci Sports Exerc. 2011;43(6):1125-31.

24. Bailey SJ, Blackwell JR, Wylie L, Holland T, Winyard PG, Jones AM Improvement in blood pressure after short-term inorganic nitrate 
supplementation is attenuated in cigarette smokers compared to nonsmoking controls. Nitric Oxide. 2016;61:29-37.

25. Lara J, Ogbonmwan I, Oggioni C, Zheng D, Qadir O, Ashor A, et al. Effects of handgrip exercise or inorganic nitrate supplementation on 24-h ambulatory blood pressure and peripheral arterial function in overweight and obese middle age and older adults: a pilot RCT. Maturitas. 2015;82(2): 228-35.

26. Bondonno CP, Liu AH, Croft KD, Ward NC, Shinde S, Moodley Y, et al. Absence of an effect of high nitrate intake from beetroot juice on blood pressure in treated hypertensive individuals: a randomized controlled trial. Am J Clin Nutr. 2015;102(2):368-75.

27. Kerley CP, Dolan E, Cormican L. Nitrate-rich beetroot juice selectively lowers ambulatory pressures and LDL cholesterol in uncontrolled but not controlled hypertension: a pilot study. Ir J Med Sci. 2017;186(4):895-902.

28. Gilchrist M, Winyard PG, Aizawa K, Anning C, Shore A, Benjamin N. Effect of dietary nitrate on blood pressure, endothelial function, and insulin sensitivity in type 2 diabetes. Free Radic Biol Med. 2013;60:89-97.

29. Asgary S, Afshani MR, Sahebkar A, Keshvari M, Taheri M, Jahanian E, et al. Improvement of hypertension, endothelial function and systemic inflammation following short-term supplementation with red beet (Beta vulgaris L.) juice: a randomized crossover pilot study. J Hum Hypertens. 2016;30(10):627-32.

30. Vanhatalo A, Bailey SJ, Blackwell JR, DiMenna FJ, Pavey TG, Wilkerson DP et al. Acute and chronic effects of dietary nitrate supplementation on blood pressure and the physiological responses to moderate-intensity and incremental exercise. Am J Physiol Regul Integr Comp Physiol. 2010;299(4): R1121-31.

31. Jajja A, Sutyarjoko A, Lara J, Rennie K, Brandt K, Qadir O, et al. Beetroot supplementation lowers daily systolic blood pressure in older, overweight subjects. Nutr Res. 2014;34(10):868-75.

32. Kapil V, Khambata RS, Robertson A, Caulfield MJ, Ahluwalia A. Dietary nitrate provides sustained blood pressure lowering in hypertensive patients: a randomized, phase 2, double-blind, placebo-controlled study. Hypertension. 2015;65(2):320-7.

33. Velmurugan S, Gan JM, Rathod KS, Khambata RS, Ghosh SM, Hartley A, et al. Dietary nitrate improves vascular function in patients with hypercholesterolemia: a randomized, double-blind, placebo-controlled study. Am J Clin Nutr. 2016;103(1):25-38.

34. Joris PJ, Mensink RP. Beetroot juice improves in overweight and slightly obese men postprandial endothelial function after consumption of a mixed meal. Atherosclerosis. 2013:231(1):78-83.

35. Hobbs DA, Goulding MG, Nguyen A, Malaver T, Walker CF, George TW, et al. Acute ingestion of beetroot bread increases endothelium-independent vasodilation and lowers diastolic blood pressure in healthy men: a randomized controlled trial. J Nutr. 2013;143(9):1399-405.

36. Hobbs DA, Kaffa N, George TW, Methven L, Lovegrove JA. Blood pressurelowering effects of beetroot juice and novel beetroot-enriched bread products in normotensive male subjects. Br J Nutr. 2012;108(11):2066-74.

37. Hughes WE, Ueda K, Treichler DP, Casey DP. Effects of acute dietary nitrate supplementation on aortic blood pressure and aortic augmentation index in young and older adults. Nitric Oxide. 2016;59:21-7.

38. Kapil V, Milsom AB, Okorie M, Maleki-Toyserkani S, Akram F, Rehman F, et al. Inorganic nitrate supplementation lowers blood pressure in humans: role for nitrite-derived NO. Hypertension. 2010;56(2):274-81.

39. Kemmner S, Lorenz G, Wobst J, Kessler T, Wen M, Günthner R, et al. Dietary nitrate load lowers blood pressure and renal resistive index in patients with chronic kidney disease: a pilot study. Nitric Oxide. 2017;64:7-15.

40. Ghosh SM, Kapil V, Fuentes-Calvo I, Bubb KJ, Pearl V, Milsom AB, et al. Enhanced vasodilator activity of nitrite in hypertension: critical role for erythrocytic xanthine oxidoreductase and translational potential. Hypertension. 2013;61(5):1091-102.

41. Berry MJ, Justus NW, Hauser Jl, Case AH, Helms CC, Basu S, et al. Dietary nitrate supplementation improves exercise performance and decreases blood pressure in COPD patients. Nitric Oxide. 2015;48:22-30.

42. Coles LT, Clifton PM. Effect of beetroot juice on lowering blood pressure in free-living, disease-free adults: a randomized, placebo-controlled trial. Nutr J. 2012;11:106.

43. Curtis KJ, O'Brien KA, Tanner RJ, Polkey Jl, Minnion M, Feelisch M, et al. Acute Dietary Nitrate Supplementation and Exercise Performance in COPD: A Double-Blind, Placebo-Controlled, Randomised Controlled Pilot Study. PloS one. 2015;10(12):e0144504.
44. Siervo M, Lara J, Ogbonmwan I, Mathers JC. Inorganic nitrate and beetroot juice supplementation reduces blood pressure in adults: a systematic review and meta-analysis. J Nutr. 2013;143(6):818-26.

45. Velmurugan S, Gan JM, Rathod KS, Khambata RS, Ghosh SM, Hartley A, et al. Dietary nitrate improves vascular function in patients with hypercholesterolemia: a randomized, double-blind, placebo-controlled study. Am J Clin Nutr. 2015;103(1):25-38.

46. Ormesher L, Myers JE, Chmiel C, Wareing M, Greenwood SL, Tropea T, et al. Effects of dietary nitrate supplementation, from beetroot juice, on blood pressure in hypertensive pregnant women: a randomised, double-blind, placebo-controlled feasibility trial. Nitric Oxide. 2018;80:37-44

47. Bondonno CP, Liu AH, Croft KD, Considine MJ, Puddey IB, Woodman RJ, et al. Antibacterial mouthwash blunts oral nitrate reduction and increases blood pressure in treated hypertensive men and women. Am J Hypertens. 2014;28(5):572-5.

48. Wootton-Beard PC, Brandt K, Fell D, Warner S, Ryan L. Effects of a beetroot juice with high neobetanin content on the early-phase insulin response in healthy volunteers. J Nutr Sci. 2014;3:e9. https://doi.org/10.1017/jns.2014.7.

49. Olumese $\mathrm{F}$, Oboh $\mathrm{H}$. Effects of Daily Intake of Beetroot Juice on Blood Glucose and Hormones in Young Healthy Subjects; 2016. p. 455-62.

50. dos Santos BD, Conte-Junior CA, Paschoalin VMF, Alvares TS. Quantitative and comparative contents of nitrate and nitrite in beta vulgaris $L$. by reversed-phase high-performance liquid chromatography-fluorescence. Food Anal Methods. 2016;9(4):1002-8.

51. Mcllvenna LC, Monaghan C, Liddle L, Fernandez BO, Feelisch M, Muggeridge DJ, et al. Beetroot juice versus chard gel: a pharmacokinetic and pharmacodynamic comparison of nitrate bioavailability. Nitric Oxide. 2017:64:61-7.

52. James PE, Willis GR, Allen JD, Winyard PG, Jones AM. Nitrate pharmacokinetics: taking note of the difference. Nitric Oxide. 2015:48:44-50.

53. Govoni M, Jansson EA, Weitzberg E, Lundberg JO. The increase in plasma nitrite after a dietary nitrate load is markedly attenuated by an antibacterial mouthwash. Nitric Oxide. 2008;19(4):333-7.

54. Kapil V, Haydar SM, Pearl V, Lundberg JO, Weitzberg E, Ahluwalia A. Physiological role for nitrate-reducing oral bacteria in blood pressure control. Free Radic Biol Med. 2013;55:93-100.

55. Hezel M, Weitzberg E. The oral microbiome and nitric oxide homoeostasis. Oral Dis. 2015;21(1):7-16

56. Chang PY, Hafiz MS, Boesch C. Beetroot juice attenuates glycaemic response in healthy volunteers; 2018.

57. Beals JW, Binns SE, Davis JL, Giordano GR, Klochak AL, Paris HL, et al. Concurrent beet juice and carbohydrate ingestion: influence on glucose tolerance in obese and nonobese adults. J Nutr Metab. 2017;2017:739-46.

58. Brown H, Natuanya IN, Briggs O. Post-prandial effect of beetroot (Beta vulgaris) juice on glucose and lipids levels of apparently healthy subjects; 2018. p. 60-2.

59. Sravan Kumar P, Bhaumik A, Chopra M, Devi KN. Evaluation of Anti diabetic activity of Ethanolic Extract of Beet Root (EEBT- Beta vulgaris) against Streptozocin induced diabetic Rats. J Drug Discov Ther. 2016;4(37):6.

60. Uchida-Maruki $H$, Inagaki H, Ito R, Kurita I, Sai M, Ito T. Piceatannol lowers the blood glucose level in diabetic mice. Biol Pharm Bull. 2015;38(4):629-33.

61. Vanhatalo A, Blackwell JR, L'Heureux JE, Williams DW, Smith A, van der Giezen $\mathrm{M}$, et al. Nitrate-responsive oral microbiome modulates nitric oxide homeostasis and blood pressure in humans. Free Radic Biol Med. 2018;124:21-30.

62. Hohensinn B, Haselgrübler R, Müller U, Stadlbauer V, Lanzerstorfer P, Lirk G, et al. Sustaining elevated levels of nitrite in the oral cavity through consumption of nitrate-rich beetroot juice in young healthy adults reduces salivary pH. Nitric Oxide. 2016;60:10-5.

63. Jones-Carson J, Vazquez-Torres A, van der Heyde HC, Warner T, Wagner RD, Balish E. Gamma delta T cell-induced nitric oxide production enhances resistance to mucosal candidiasis. Nat Med. 1995;1(6):552-7.

64. Duncan C, Dougall H, Johnston P, Green S, Brogan R, Leifert C, et al. Chemical generation of nitric oxide in the mouth from the enterosalivary circulation of dietary nitrate. Nat Med. 1995;1(6):546-51.

65. Dejam A, Hunter CJ, Gladwin MT. Effects of dietary nitrate on blood pressure. N Engl J Med. 2007;356(15):1590 author reply.

66. Hendgen-Cotta UB, Luedike P, Totzeck M, Kropp M, Schicho A, Stock P, et al. Dietary nitrate supplementation improves revascularization in chronic ischemia. Circulation. 2012;126(16):1983-92. 
67. Loscalzo J. Antiplatelet and antithrombotic effects of organic nitrates. Am J Cardiol. 1992;70(8):18b-22b.

68. Panghal A, Virkar K, Kumar V, Dhull S, Gat Y, Chhikara N. Development of Probiotic Beetroot Drink; 2017.

69. Klewicka E, Zduńczyk Z, Juśkiewicz J, Klewicki R. Effects of lactofermented beetroot juice alone or with $\mathrm{N}$-nitroso-N-methylurea on selected metabolic parameters, composition of the microbiota adhering to the gut epithelium and antioxidant status of rats. Nutrients. 2015;7(7):5905-15.

70. Klewicka E, Nowak A, Zduńczyk Z, Cukrowska B, Btasiak J. Protective effect of lactofermented beetroot juice against aberrant crypt foci formation and genotoxicity of fecal water in rats. Exp Toxicol Pathol. 2012;64(6):599-604.

71. Kapadia GJ, Azuine MA, Sridhar R, Okuda Y, Tsuruta A, Ichiishi E, et al. Chemoprevention of DMBA-induced UV-B promoted, NOR-1-induced TPA promoted skin carcinogenesis, and DEN-induced phenobarbital promoted liver tumors in mice by extract of beetroot. Pharmacol Res. 2003:47(2):141-8.

72. Sreekanth D, Arunasree M, Roy KR, Reddy TC, Reddy GV, Reddanna P. Betanin a betacyanin pigment purified from fruits of Opuntia ficus-indica induces apoptosis in human chronic myeloid leukemia cell line-K562. Phytomedicine. 2007;14(11):739-46.

73. Czyżowska A, Klewicka E, Libudzisz Z. The influence of lactic acid fermentation process of red beet juice on the stability of biologically active colorants. Eur Food Res Technol. 2006;223(1):110-6.

74. Klewicka E, Zduńczyk Z, Juśkiewicz J. Effect of lactobacillus fermented beetroot juice on composition and activity of cecal microflora of rats. Eur Food Res Technol. 2009;229(1):153-7.

75. Butt MS, Randhawa MA, Shahid M. Nephroprotective effects of red beetroot-based beverages against gentamicin-induced renal stress. J Food Biochemistry. 2016;103:e12873.

76. Batchelor AM, Bartus K, Reynell C, Constantinou S, Halvey EJ, Held KF, et al. Exquisite sensitivity to subsecond, picomolar nitric oxide transients conferred on cells by guanylyl cyclase-coupled receptors. Proc Natl Acad Sci U S A. 2010;107(51):22060-5.

77. Gao X, Yang T, Liu M, Peleli M, Zollbrecht C, Weitzberg E, et al. NADPH oxidase in the renal microvasculature is a primary target for blood pressure-lowering effects by inorganic nitrate and nitrite. Hypertension. 2015;65(1):161-70.

78. Hezel M, Peleli M, Liu M, Zollbrecht C, Jensen BL, Checa A, et al. Dietary nitrate improves age-related hypertension and metabolic abnormalities in rats via modulation of angiotensin II receptor signaling and inhibition of superoxide generation. Free Radic Biol Med. 2016;99:87-98.

79. El Gamal AA, AISaid MS, Raish M, Al-Sohaibani M, Al-Massarani SM, Ahmad A, et al. Beetroot (Beta vulgaris L.) extract ameliorates gentamicin-induced nephrotoxicity associated oxidative stress, inflammation, and apoptosis in rodent model. Mediat Inflamm. 2014:2014:e0144504.

80. Singh A, Verma S, Singh V, Nanjappa C, Roopa N, Raju P. Beetroot juice supplementation increases high density lipoprotein-cholesterol and reduces oxidative stress in physically active individuals. J Pharm Nut Sci. 2015;5(3): 179-85.

81. Shepherd Al, Wilkerson DP, Fulford J, Winyard PG, Benjamin N, Shore AC, et al. Effect of nitrate supplementation on hepatic blood flow and glucose homeostasis: a double-blind, placebo-controlled, randomized control trial. Am J Physiol Gastrointest Liver Physiol. 2016;311(3):G356-G64.

82. Fuchs D, Nyakayiru J, Draijer R, Mulder TP, Hopman MT, Eijsvogels TM, et al. Impact of flavonoid-rich black tea and beetroot juice on postprandial peripheral vascular resistance and glucose homeostasis in obese, insulinresistant men: a randomized controlled trial. Nutr Metab. 2016;13(1):34.

\section{Publisher's Note}

Springer Nature remains neutral with regard to jurisdictional claims in published maps and institutional affiliations.

Ready to submit your research? Choose BMC and benefit from:

- fast, convenient online submission

- thorough peer review by experienced researchers in your field

- rapid publication on acceptance

- support for research data, including large and complex data types

- gold Open Access which fosters wider collaboration and increased citations

- maximum visibility for your research: over $100 \mathrm{M}$ website views per year

At BMC, research is always in progress.

Learn more biomedcentral.com/submissions 